Article

\title{
Determinants of Individuals' E-Waste Recycling Decision: A Case Study from Romania
}

\author{
Camelia Delcea ${ }^{1, *} \mathbb{0}$, Liliana Crăciun ${ }^{2}$, Corina Ioanăș ${ }^{3}$, Gabriella Ferruzzi ${ }^{4}$ and \\ Liviu-Adrian Cotfas ${ }^{1}$ (D) \\ 1 Department of Economic Informatics and Cybernetics, Bucharest University of Economic Studies, \\ 010552 Bucharest, Romania; liviu.cotfas@ase.ro \\ 2 Department of Economics and Economic Policies, Bucharest University of Economic Studies, \\ 010552 Bucharest, Romania; liliana.craciun@softscape.ro \\ 3 Department of Accounting, Bucharest University of Economic Studies, 010552 Bucharest, Romania; \\ corina.ioanas@softscape.ro \\ 4 Department of Industrial Engineering, University of Naples Federico II, 80125 Naples, Italy; \\ gabriella.ferruzzi@unina.it \\ * Correspondence: camelia.delcea@csie.ase.ro
}

Received: 9 March 2020; Accepted: 29 March 2020; Published: 1 April 2020

\begin{abstract}
Due to the increase of the amount of electrical and electronical equipment waste (e-waste), the understanding of individual consumers' main decision triggers represents a key point in increasing the quantity of recycled e-waste. A series of studies from the literature have shown a positive relationship between the consumers' attitude, awareness, self-efficacy, social norms, and their e-waste recycling intention, as well as the positive influence between the intention and the manifested behavior. Additional to these determinants, in the present study, the influence of social media was analyzed along with the actions taken by the government and nongovernmental organizations, with the purpose to include and to capture, as much as possible, a high amount of determinants in the e-waste recycling process. Nevertheless, the demographic or socio-economic variables, such as age, gender, income, education, number of family members, etc., have shown over time to have a contribution to predicting the consumers' pro-recycling behavior. As on one side, in the research literature, the opinions related to which of the demographic or socio-economic factors can have an impact on the recycling behavior have been divided and, on another side, a series of researchers believe that the discrepancies in the findings of different studies can be due to culture in various countries, in this paper we conducted such an analysis with reference to the Romania's case. The results have shown that the demographic variables, such as age and gender, can have a contribution to predicting residents' pro-e-waste recycling behavior. Based on these findings, the policymakers can gain a better understanding of the e-waste recycling phenomenon and on its main triggers, with results in creating better policies for sustaining a proper e-waste managing system.
\end{abstract}

Keywords: e-waste recycling; consumers' decisions; recycling behavioral intention; structural equation modeling; Romania; social media influence

\section{Introduction}

E-waste (waste electrical and electronical equipment, WEEE) refers to any discarded products that have a battery or a plug, and have ceased to represent value to their users or no longer satisfy their initial purpose [1]. Various types of waste products can be included in the e-waste category, such as, but not limited to: washing machines, dishwashers, air conditioners, refrigerators, microwaves, toasters, coffee machines, appliances for toothbrushing, shaving, hair drying, laptops, personal computers, notebooks, 
telephones, cell phones, printers, electronical and electronic tools, leisure equipment, medical devices, monitoring and control instruments, automatic dispensers, etc.

A high amount of e-waste is currently generated worldwide at an estimated annual growth rate between $4 \%$ and $5 \%$, and with an expected amount of more than 50 million tons in 2021 [2]. Blade et al. [3] determined that in 2016, Asia generated almost $40.7 \%$ of the global e-waste, followed by Europe with $27.4 \%$ of the global waste, and America with $25.3 \%$. Smaller percentages have been brought by Africa (5\%) and Oceania (1.6\%). Regarding the percentage of collected e-waste, Europe collected almost $35 \%$ of the e-waste generated in the countries, followed by America with 17\%, and Asia with $15 \%$. Even in this case, Oceania collected a small amount, with a rate of $6 \%$, while for Africa, the numbers presented a $0 \%$ collected rate (representing in absolute value 0.004 million tons) [3].

Considering the numbers for Europe, according to Eurostat [4], in 2017 the recycling rate of e-waste has been below $50 \%$ for most European countries, except for Estonia, Bulgaria, Iceland, Hungary, and Austria, which passed the 50\% e-waste recycling threshold, and Croatia and Liechtenstein, which hit scores above $80 \%$. The smallest e-waste recycling rates have been recorded in Greece, Lithuania, and Poland. Figure 1 presents the recycling rate of the e-waste in 2017 only for the countries for which this information was available on the database offered by Eurostat.

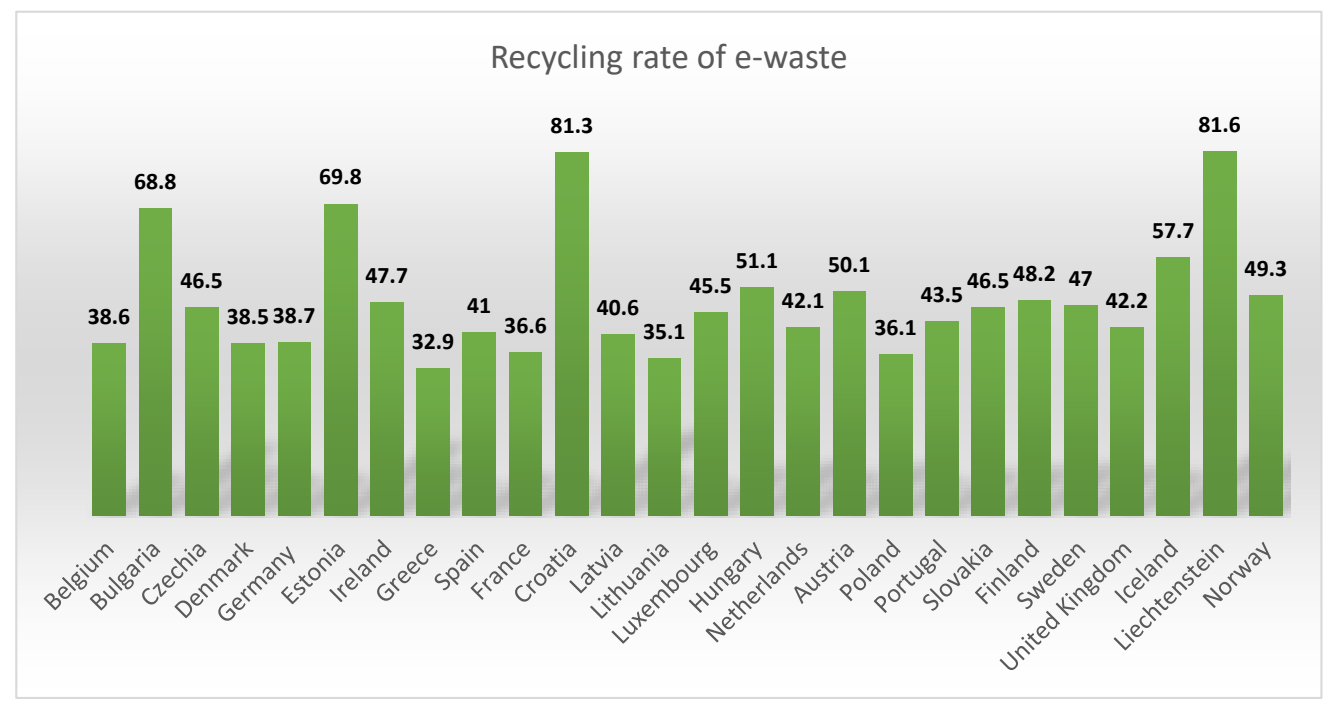

Figure 1. Recycling rate of e-waste in Europe in 2017 (source: Eurostat [4]).

Regarding the volume of e-waste generated in the European Union, including Norway and Switzerland, it is estimated that in 2020 it will reach 10,960,799 tons [5]. By categories (considering six main categories) of e-waste, the highest value is being recorded for large equipment (3,656,468 tons) and small equipment $(3,392,044$ tons). The temperature exchange equipment e-waste is estimated at $1,853,605$ tons, while screens at 1,083,991 tones. Lower values are estimated for small IT (900,695 tons) and lamps (73,996 tons) [5].

Not only does the weight or the quantity of the yearly generated e-waste represent a high level of pressure for the environment and for the measures needed to be taken in order to properly recycle the electronic products, but the damage that the e-waste produces in the environment is also significant. From this point of view, even though globally the e-waste represents almost $5 \%$ of all municipal solid waste [1], the toxicity brought to the environment by this type of waste is high, representing almost $70 \%$ of our overall toxic waste [6]. The environmental and health impacts of the e-waste have been largely discussed in the research literature attached to this field [7-10]. Also, Shevchenko et al. [11] underlined that more than 1000 different substances are included in the e-waste category, many of them toxic to both human health and environment, while $70 \%$ of the cadmium and mercury present in the USA's landfills are from e-waste. 
In this context, the environmental and health protection is a key point in the current economy, and measures should be taken for encouraging the e-waste recycling process as a part of the overall recycling process. The need to have a clean environment is widely acknowledged in the scientific literature [12-14]. Moreover, extensive efforts have been made for the optimization of the environmental bioprocess on the path towards a green economy [15]. Guidelines for adopting a circular economy are presented in [16].

Due to issues connected to the management system of the e-waste handling, households deal with higher challenges in the recycling process of e-waste than companies [17-19]. Nevertheless, households play an important role in participating to this process, and besides the awareness, attitude, responsibility, self-efficacy, and other aspects that can contribute to individuals' intention of recycling the e-waste, the occurrence of social media and of the actions taken by the government and NGOs (nongovernmental organizations) might have a positive impact on the overall e-waste recycling process [20].

In January 2020, the penetration rate of the social media recorded high values for countries in Eastern Asia (71\%), Northern America (69\%), Northern Europe, and Southern America (67\%) [21]. Smaller penetration rates have been recorded for different parts of Africa (between 6\%-39\%), contributing to a global social media penetration rate of $49 \%$ [21]. Considering the areas with the highest e-waste production, it can be observed that these are also the areas in which social media has succeed to penetrate at a higher rate.

As the topic of e-waste recycling is vast, a series of papers have addressed this problem in different countries contexts such as: Brazil [22], Canada [23], China [24-28], Costa Rica [29], Ghana [30,31], Greece [32], Hong Kong [24], India [33], Italy [34], Japan [26], Mexico [35,36], New Zealand [7], Nigeria [19,37], South Korea [26], Sri Lanka [38], Taiwan [26,39], United Kingdom [40], United States [41], Vietnam [42], etc., by studying various aspects related to the e-waste recycling process in the context of the behavior of the consumers' located in these areas.

Given the fact that, to the best of our knowledge, there is little evidence regarding the e-waste determinants in the case of Romania, the current study aimed to analyze these determinants from multiple points of view. In order to underline more the importance of the e-waste recycling process in the context of Romania, it should be mentioned that even though efforts have been made in this direction (as there are over 2000 collection points in commercial networks [43]), Romania is facing serious problems regarding the e-waste management [43]. According to Păceșilă et al. [43], the total amount of electrical and electronic equipment was about $25-30 \mathrm{~kg} / \mathrm{capita}$ in 2016, while the e-waste collected in the same period was $1.6 \mathrm{~kg} / \mathrm{capita}$ [44], lower than the European Union average of $8.9 \mathrm{~kg} / \mathrm{capita}$.

Projected data from Urban Mine Platform [45] for 2020 show that $12.81 \mathrm{~kg} / \mathrm{capita}$ of waste will be generated in Romania (higher than the $12.56 \mathrm{~kg} / \mathrm{capita}$ in 2019), most of it belonging to large equipment (4.53 kg/capita), small equipment (3.09 kg/capita), and temperature exchange equipment (3.01 kg/capita), while small amounts come from small IT (0.59 kg/capita) and lamps (0.12 kg/capita).

In this context, the paper aimed to identify the main factors that can influence consumers' behavior towards e-waste recycling and to analyze whether some of the demographic and/or socio-economic variables can have an effect on the e-waste recycling and intention.

The remainder of the paper is structured as follows: Section 2 provides a literature review on the topic of e-waste and how different aspects related to it have been addressed in the scientific literature. Section 3 presents the methodology associated to this study, highlighting the elements considered in the questionnaire and stating the main hypotheses of the study. Section 4 provides the results gathered through the use of the questionnaire and analysis of them in terms of demographic and socio-economic variables. The paper ends with a concluding remarks section, in which the limitations of this study are discussed.

\section{Literature Review}

The recorded population growth combined with the rapid changes and advances in technologies has facilitated the increase of the waste generated worldwide [37,46-49], among which, e-waste plays an important role due to the harmful effects on both environment and health. 
A broad range of research has been written in the area of e-waste recycling, addressing the issue from different point of views. Wang et al. [50] underlined the fact that when e-waste recycling is done with responsibility, it does not only reduce the quantity of waste that is disposed in landfills but it is also a beneficial process in recovering the valuable materials, such as nonprecious metals (aluminum, steel, copper, iron, etc.), precious metals (such as platinum, gold, silver, etc.), and plastic. In a recent study, Vaccari et al. [51] conducted an overview study considering both the environmental pollution and the health consequences, and showed that high levels of pollutants have been discovered in the bodies of the persons living or working in the areas with informal e-waste treatment. The authors have shown that not only the human health suffered from the informal working activity related to the e-waste treatment, but even the soil, air, and water have been contaminated with heavy metals and organic contaminants [51].

Arain et al. [52] showed in a recent work that the consumers' behavior is critical in managing and reducing the e-waste. In order to better shape the consumers' behavior, the authors have conducted a study in a university environment and have observed that lack of consumer knowledge about products and disposal sites plays an important role in consumer decisions. Even more, the free access to disposal and recycling facilities within a reasonable distance positively influences the consumers' decision to participate in the recycling process [52]. Even more, recycling opportunities and reduced distance to collection points have been named as underlying factors for e-waste recycling by [53-55]. Rousta et al. [54] have determined that a decreased distance to drop-off points resulted in improved sorting of recyclables, while the missorted fraction depended on the proper information received by the recycling persons.

Also, consumers' awareness has been proved to have a direct relationship with the willingness of e-waste recycling [56]. The role of households' awareness is underlined by Miner et al. [19], who believed that a well informed and aware population can make better decisions related to handling the e-waste. Along with the awareness manifested by the consumer, a pro-recycling attitude has been determined to have a major contribution to the recycling behavior [40].

Intrinsic factors, such as personal and social norms and understanding the consequences of a given behavior, are triggers for the peoples' intention, having at the same time a mediated influence on behavior $[40,57]$.

The importance of the government and NGOs has been stated in [29]. The authors presented in their work the steps followed in Costa Rica in order to develop a better e-waste management system and the role played by different organizations in promotion and increasing the population awareness regarding their responsibility in the e-waste management process [29]. Also, D'Adamo et al. [58], focusing on end of life vehicles, have shown that it is important for carbon price to increase in order to promote recycling.

By focusing on the e-waste recycling process and considering the presence of the online environment and its influence on the e-waste recycling process, Wang et al. [59] explored the factors influencing this process and identified that subjective norms, economic motivation, the level of income and education, the perceived behavioral control, and behavioral attitudes affect the online recycling intention in a positive manner.

With the development of social media, a series of studies have presented the role of consumers' influence on these networks [60-65], proving that the social influence positively affects the people's behavior when adopting a pro-environment attitude [49,66]. Sujata et al. [20] analyzed in their study the determinants of recycling intention behavior for the general public. Using a questionnaire approach, the authors have observed a positive relation between attitude, social norms, self-efficacy, social media usage, and recycling intention. Even more, the authors have considered the role of government and NGOs from the recyclers' perspective and have extracted the feelings the respondents had with regard to the actions taken by the government and NGOs. As a result, it has been observed that the recyclers' intention and their opinion upon the NGOs activity influence the recycling behavior, while 
the moderating role of the government seemed not to be significant to the recycling behavior of the consumers [20].

Considering a broad range of papers, Shevchenko et al. [11] have analyzed consumers' recycling behavior determinants by considering 27 papers written on different continents (Europe, America, Asia, and Africa). Among the most listed determinant, one can highlight the awareness and knowledge level, followed by convenience and economic incentives. Other determinants considered in the selected studies are: gender, current habits, legislative norms and trustworthiness, mentality and attitude, income, age, and educational level [11]. Piligrimiene et al. [67] have divided the factors influencing the consumer engagement into two main categories: internal factors (environmental attitude, perceived responsibility, perceived behavioral efficiency) and external factors (conditions for sustainable conditions, social environment, and promotion of sustainable conditions).

Other areas of study related to the e-waste recycling process have addressed, but are not limited to: stress and occupational noise exposure in the case of e-waste recycling workers $[31,68]$, public awareness regarding the informal sector's involvement in managing e-waste [33], developing an e-waste sorting methodology [69], the effect of macroeconomic and social factors on illegal e-waste trade [70], the link between gross domestic product (GDP) and e-waste [71].

\section{Material and Methods}

\subsection{Survey Design}

Based on the papers mentioned above and by considering a series of other studies from a broader range of papers referring to the general recycling process and the way humans actions can be influenced (such as [72-81]), a 54-questions survey was generated. Due to the validation process of the questionnaire, the number of questions was reduced due to low loadings as suggested by [20], with a 41-questions construction remaining after the validation. The questions included in the validated construction are presented in Appendix A (Table A1). The main focus was to keep in the survey the elements that seemed to have an influence on the e-waste recycling intention and on the behavior associated to e-waste recycling.

For this purpose, the aspects considered in the case of consumers' e-waste recycling process were: attitude (AT), awareness (AW), self-efficacy (SE), responsibility (RESP), social norms (SN), social influence (SI), social media (SM), government and NGOs' actions (GNGO), recycling intention (RI), convenience (CONV), government measures (GM, compressing ideas related to the legislative actions the government should make), and recycling behavior (RB)-Figure 2. The considered aspects were inspired by the elements analyzed in various research papers written in the literature associated with the consumer recycling behavior (as presented in the literature review section). All the questions in these categories have been valuated using a 5-point Likert scale, with 1-strongly disagree, 2-disagree, 3-neutral, 4-agree, and 5-strongly agree [82].

Besides the questions associated with these categories, some demographic data were also extracted, along with information related to ownership and knowledge of the e-waste products and the degree of usage of social media platforms, time spent on these platforms, and the degree to which the respondent can be influenced by the posts, videos, links, advertisements, and friends' attitudes on these platforms. These questions allowed the respondents to choose one or more option from a list of possible options or asked the respondents to write their answers inside text fields.

\subsection{Distribution}

The questionnaire was created and hosted using Google Forms and was distributed through a series of social media platforms. All the questions were marked as "mandatory" in order to submit the form, assuring in this way that we were not faced with an empty data case.

The questionnaire was available for three weeks in the fall of 2019. No incentives were given for participation. A number of 532 valid questionnaires were filled in. 


\subsection{Data Analysis}

Data gathered through the questionnaire were analyzed using IBM SPSS Amos version 22 [83]-Figure 3.

Descriptive statistics and analysis were run over the data set. The results obtained through this analysis are presented in detail in the next section of the paper.

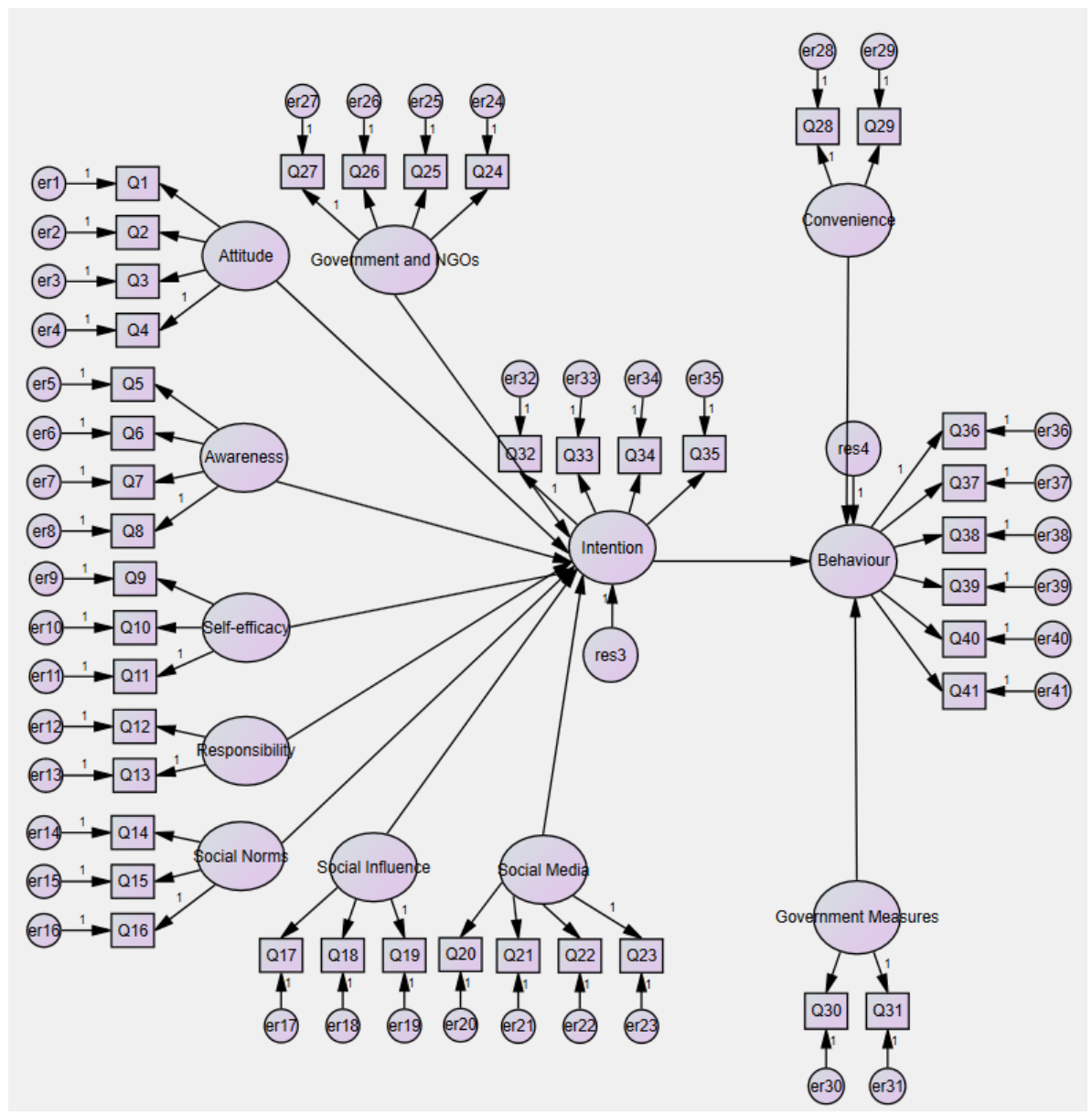

Figure 2. The considered construction.

The questionnaire was validated through a confirmatory factor analysis [84]. This analysis was conducted using IBM SPSS Amos 22. The unidimensionality, feasibility, convergent validity, and similarity validity were considered in accordance with the recommendations [85] from the field.

The standardized regression weights were used in order to test the unidimensionality. For a proper validation of the unidimensionality, all these factor loading values should exceed 0.5 . In our model, all the standardized regression weights were above this threshold, except for the one between the self-efficacy and responsibility, which was close to this value, but slightly below, reaching 0.492 .

Feasibility and convergent validity are tested through average variance extracted (AVE) and construct reliability (CR). The used software does not offer the possibility to automatically compute the values corresponding to these indicators. AVE and CR were manually computed using the formulas in [84] and their associated values can be found in Table 1. As a general rule, the values recorded for CR should be greater than 0.7 in order to suggest a good feasibility (other studies suggest that a value between 0.6 and 0.7 is also acceptable [42,85]). Considering the values for the CR presented in Table 1 , it can be observed that all of them exceeded the imposed threshold value, even more, all the values for the CR were above 0.7. Regarding the expected values for AVE, it is acknowledged that a value above 0.5 proves a good convergent validity [42,85]. Values between 0.4 and 0.5 might also prove a 
good convergent validity if the associated CR values are above 0.6 , according to $[42,86]$. In our case, three of the twelve constructions considered had values for the AVE in the 0.4-0.5 range, while all the others were hitting values above the imposed threshold of 0.5. Based on the research literature, we could conclude that given the values obtained for AVE and CR, the feasibility and convergent validity criterion were passed.

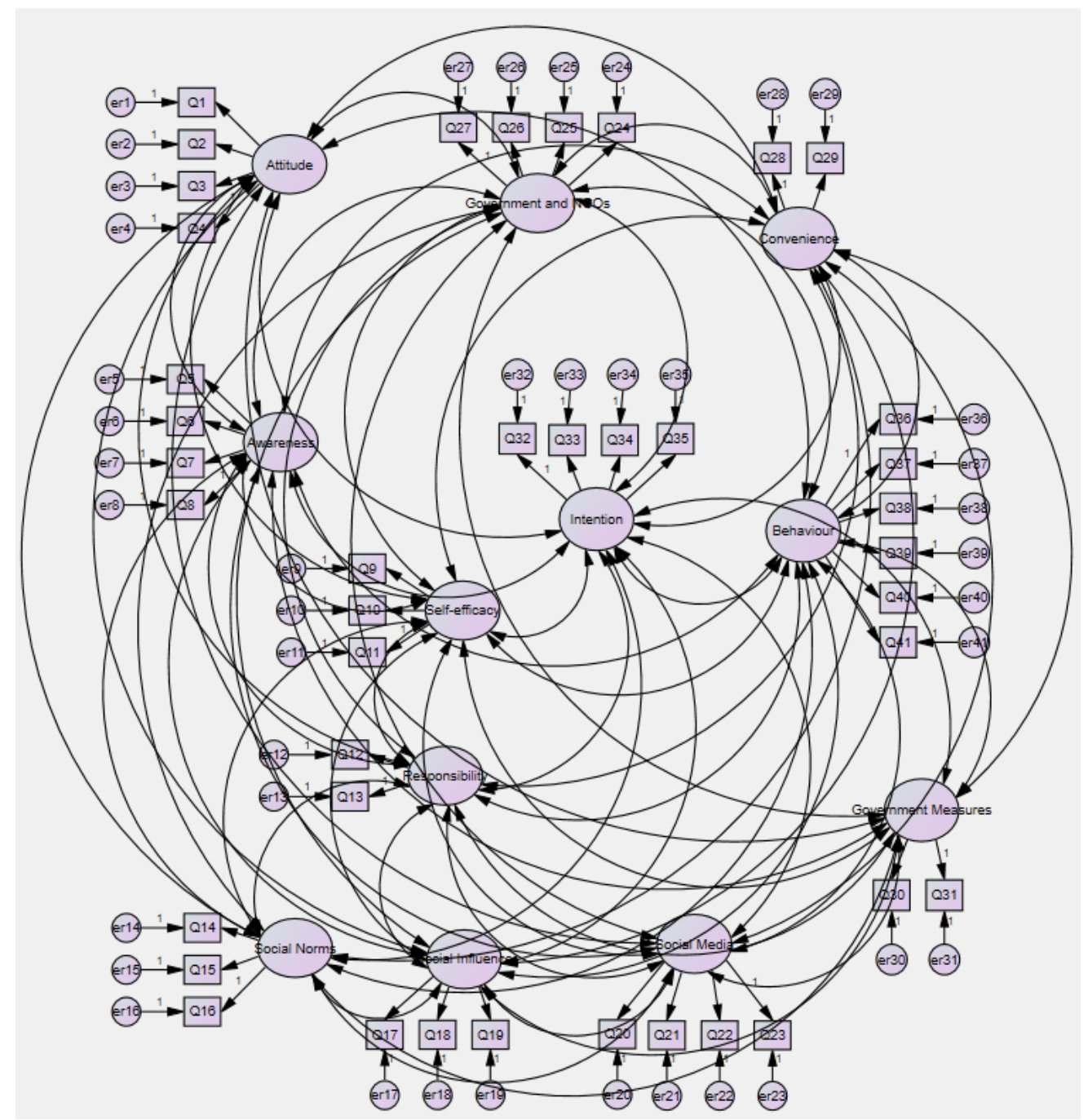

Figure 3. The individual components validation process.

The goodness of fit (GOF) measures were used for validating the construct similarity. These measures are listed under the "model fit summary" section in IBM SPSS Amos. The fit indexes can take values up to a maximum value of 1 , being recommended to reach values above 0.9-0.95. In our case, the comparative fit index (CFI) reached a value of 0.922 , which is considered acceptable given the size of the sample, the high number of individual construction components, and the number of questions.

Also, for a more in-depth analysis, it is recommended to check the values for the normed fit index (NFI) [87], which in our case was 0.851. Even more, the values for relative fit index (RFI) [87] should be considered, having in our case a value of 0.833. Last, the incremental fit index (IFI) [87] was 0.923, which is considered adequate given the size of the model. 
Table 1. Standardized regression weights, average variance extracted (AVE), and construct reliability (CR).

\begin{tabular}{|c|c|c|c|c|c|c|c|c|c|c|c|c|}
\hline & AT & AW & SE & RESP & SN & SI & SM & GNGO & CONV & GM & RI & RB \\
\hline Q1 & 0.796 & & & & & & & & & & & \\
\hline $\mathrm{Q} 2$ & 0.848 & & & & & & & & & & & \\
\hline Q3 & 0.723 & & & & & & & & & & & \\
\hline$\widehat{Q} 4$ & 0.835 & & & & & & & & & & & \\
\hline Q5 & & 0.580 & & & & & & & & & & \\
\hline Q6 & & 0.732 & & & & & & & & & & \\
\hline Q7 & & 0.856 & & & & & & & & & & \\
\hline Q8 & & 0.876 & & & & & & & & & & \\
\hline Q9 & & & 0.864 & & & & & & & & & \\
\hline Q10 & & & 0.853 & & & & & & & & & \\
\hline Q11 & & & 0.691 & & & & & & & & & \\
\hline Q12 & & & & 0.786 & & & & & & & & \\
\hline Q13 & & & & 0.773 & & & & & & & & \\
\hline Q14 & & & & & 0.609 & & & & & & & \\
\hline Q15 & & & & & 0.726 & & & & & & & \\
\hline Q16 & & & & & 0.556 & & & & & & & \\
\hline Q17 & & & & & & 0.713 & & & & & & \\
\hline Q18 & & & & & & 0.794 & & & & & & \\
\hline Q19 & & & & & & 0.797 & & & & & & \\
\hline Q20 & & & & & & & 0.749 & & & & & \\
\hline Q21 & & & & & & & 0.573 & & & & & \\
\hline$\widehat{\mathrm{Q}} 22$ & & & & & & & 0.667 & & & & & \\
\hline Q23 & & & & & & & 0.616 & & & & & \\
\hline Q24 & & & & & & & & 0.518 & & & & \\
\hline Q25 & & & & & & & & 0.837 & & & & \\
\hline Q26 & & & & & & & & 0.781 & & & & \\
\hline Q27 & & & & & & & & 0.812 & & & & \\
\hline Q28 & & & & & & & & & 0.603 & & & \\
\hline Q29 & & & & & & & & & 0.837 & & & \\
\hline
\end{tabular}


Table 1. Cont.

\begin{tabular}{|c|c|c|c|c|c|c|c|c|c|c|c|c|}
\hline & $\mathrm{AT}$ & AW & SE & RESP & SN & SI & SM & GNGO & CONV & GM & RI & RB \\
\hline Q31 & & & & & & & & & & 0.652 & & \\
\hline Q32 & & & & & & & & & & & 0.904 & \\
\hline Q33 & & & & & & & & & & & 0.600 & \\
\hline Q34 & & & & & & & & & & & 0.737 & \\
\hline Q35 & & & & & & & & & & & 0.658 & \\
\hline Q36 & & & & & & & & & & & & 0.838 \\
\hline Q37 & & & & & & & & & & & & 0.833 \\
\hline Q38 & & & & & & & & & & & & 0.868 \\
\hline Q39 & & & & & & & & & & & & 0.848 \\
\hline Q40 & & & & & & & & & & & & 0.549 \\
\hline$\hat{\mathrm{Q}} 41$ & & & & & & & & & & & & 0.692 \\
\hline AVE & 0.643 & 0.593 & 0.651 & 0.608 & 0.402 & 0.591 & 0.428 & 0.560 & 0.532 & 0.472 & 0.538 & 0.634 \\
\hline CR & 0.928 & 0.906 & 0.907 & 0.846 & 0.763 & 0.884 & 0.829 & 0.892 & 0.787 & 0.750 & 0.884 & 0.936 \\
\hline
\end{tabular}


Even more, Brown [87] and Byrne [88] recommended the use of the Tucker-Lewis index (TLI), which should be around the value of 0.95 . For our model, the Tucker-Lewis index was 0.912 , also acceptable considering the size of the model.

A root mean square error of approximation (RMSEA) below 0.06 signifies a good model fit according to Hu and Bentler [89], Harrington [90], and Paswan [91]. In our case the RMSEA of $0.059<$ 0.06, within the imposed threshold value. Even more, Paswan [91] recommended a threshold value of 0.085 for the LO90 and HI90 intervals. For the model under investigation, the LO90 was 0.054, while HI90 was 0.064 , being in the imposed range.

\subsection{Hypotheses}

Based on the literature presented in Section 2, the following hypotheses have been considered:

Hypothesis (H1): Attitude towards e-waste recycling positively affects consumers' e-waste recycling intention.

Hypothesis (H2): E-waste recycling awareness positively affects consumers' e-waste recycling intention.

Hypothesis (H3): Self-efficacy positively affects consumers' e-waste recycling intention.

Hypothesis (H4): Responsibility positively affects consumers' e-waste recycling intention.

Hypothesis (H5): Social norms have a positive impact on e-waste recycling intention.

Hypothesis (H6): Social influence positively affects individuals' e-waste recycling intention.

Hypothesis (H7): Social media has a positive impact on individuals' e-waste recycling intention.

Hypothesis (H8): Government and NGOs' actions positively contribute to consumers' e-waste recycling intention.

Hypothesis (H9): Recycling intention positively affects the recycling decision in the case of e-waste.

Hypothesis (H10): Government measures have a positive impact on consumers' e-waste recycling decision.

Hypothesis (H11): Convenience positively affects the consumers' e-waste recycling decision.

The considered hypotheses are summarized in Figure 4.

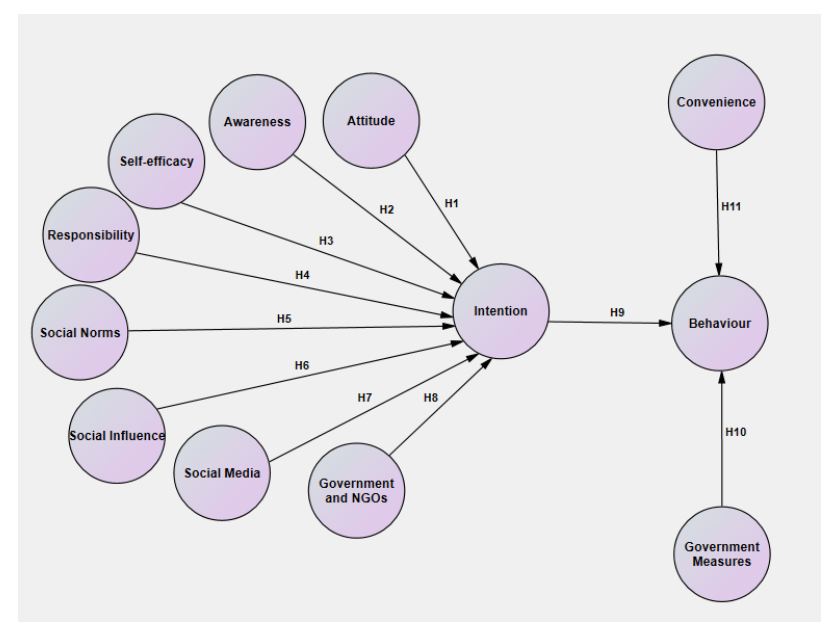

Figure 4. The hypotheses framework. 


\section{Case Study}

\subsection{Demographic and Socio-Economic Characteristics}

The research focused both on the elements stated in the literature that might contribute to consumers' intention or decision to participate in the e-waste recycling, such as attitude, awareness, self-efficacy, responsibility, social norms, and convenience, but also on the elements related to the emergence of social media and the influence exerted among the consumers due to their online activity and the actions made by the government and NGOs.

As the questionnaire was distributed to the online social platforms, it ensured that all the respondents had access to social media platforms, therefore, none of the valid questionnaires had to be removed from the completed questionnaire database. As a result, a number of 532 questionnaires were validated and used for the analysis. The demographic and socio-economic characteristics of the respondents are presented in Table 2.

Table 2. Demographic and socio-economic profile of respondents ( $\mathrm{n}=532$ persons).

\begin{tabular}{|c|c|c|c|}
\hline Demographic and Socio-Economic Variables & Group/Components & Frequency & Percentage \\
\hline \multirow{2}{*}{ Gender } & Female & 317 & $59.59 \%$ \\
\hline & Male & 215 & $40.41 \%$ \\
\hline \multirow{3}{*}{ Age } & $18-30$ & 198 & $37.22 \%$ \\
\hline & $30-50$ & 251 & $47.18 \%$ \\
\hline & $\geq 50$ & 83 & $15.60 \%$ \\
\hline \multirow{3}{*}{ Educational level } & Secondary education & 157 & $29.51 \%$ \\
\hline & University & 294 & $55.26 \%$ \\
\hline & Post-university & 81 & $15.23 \%$ \\
\hline \multirow{2}{*}{ Residential area } & Urban & 385 & $72.37 \%$ \\
\hline & Rural & 147 & $27.63 \%$ \\
\hline \multirow{2}{*}{ Marital status } & Single & 169 & $31.77 \%$ \\
\hline & Married & 363 & $68.23 \%$ \\
\hline \multirow{4}{*}{ Occupation } & Services & 207 & $38.91 \%$ \\
\hline & Production & 144 & $27.07 \%$ \\
\hline & Student & 102 & $19.17 \%$ \\
\hline & Others & 79 & $14.85 \%$ \\
\hline \multirow{3}{*}{ Family size } & 1-2 persons & 162 & $30.45 \%$ \\
\hline & 3-4 persons & 259 & $48.68 \%$ \\
\hline & $\geq 5$ persons & 111 & $20.87 \%$ \\
\hline \multirow{3}{*}{ Income (per month) } & $\leq 500 €$ & 130 & $24.44 \%$ \\
\hline & $500-1000 €$ & 327 & $61.46 \%$ \\
\hline & $\geq 1000 €$ & 75 & $14.10 \%$ \\
\hline \multirow{4}{*}{ Number of years in e-waste recycling } & Do not practice & 112 & $21.05 \%$ \\
\hline & $\leq 1$ year & 106 & $19.92 \%$ \\
\hline & $1-3$ years & 223 & $41.92 \%$ \\
\hline & $\geq 3$ years & 91 & $17.11 \%$ \\
\hline
\end{tabular}


Table 2. Cont.

\begin{tabular}{cccc}
\hline Demographic and Socio-Economic Variables & Group/Components & Frequency & Percentage \\
\hline \multirow{3}{*}{ Number of hours spent on social media } & $\leq 1 \mathrm{~h}$ & 92 & $17.29 \%$ \\
\cline { 2 - 3 } & $1-2 \mathrm{~h}$ & 154 & $28.95 \%$ \\
\cline { 2 - 3 } & $3-4 \mathrm{~h}$ & 271 & $50.94 \%$ \\
\hline \multirow{2}{*}{ Most frequently used social media } & $\geq 5 \mathrm{~h}$ & 15 & $2.82 \%$ \\
\cline { 2 - 4 } & Facebook & 57 & $10.71 \%$ \\
\cline { 2 - 4 } & Twitter & 199 & $37.41 \%$ \\
\cline { 2 - 3 } & Instagram & 36 & $6.77 \%$ \\
\hline
\end{tabular}

Regarding the period of engagement in e-waste recycling, $21.05 \%$ marked that they had not previously engaged in the e-waste recycling process, while the vast majority, $41.92 \%$, were practicing it for 1-3 years. A smaller number of respondents, 91 persons (17.11\%), marked the fact that they were engaged in the e-waste recycling for more than 3 years.

The use of social media was measured through the number of hours spent by the respondents on various sites. The great majority of the respondents spent $3-4 \mathrm{~h}$ on social media (50.94\%), while $28.95 \%$ of the respondents spent 1-2 h. Among the most popular social networks, Facebook represented the most used platform ( $44.55 \%$ of the respondents marking it as their most frequently used social media platform), followed by Instagram (37.41\%) and Twitter (10.71\%).

\subsection{E-Waste Behavior}

The respondents' behavior related to the e-waste products recycling is analyzed in the following. Besides the answers to the questions presented in Appendix A, in this section, few other aspects will be presented related to the degree to which the respondents know how to recognize the products that can be included in the e-waste category, the level of ownership of these products, and how social media influence is manifested in their case, namely how prone to be influenced by the opinions expressed by other persons in these environments they are.

\subsubsection{Attitude and Awareness of E-Waste Recycling}

The items related to consumers' attitude regarding the e-waste recycling have showed that, in general, the respondents possessed a good opinion related to the whole e-waste recycling process.

It was observed that $74.06 \%$ of the respondents marked that e-waste recycling is a part of a responsible citizen's life, while only $8.27 \%$ disagreed or strongly disagreed with this idea, $17.67 \%$ having no particular opinion on the subject-Figure 5 .

A similar percentage, $76.88 \%$ of the respondents believed that a pro-environment behavior is necessary given the current development conditions, while only $10.53 \%$ disagreed with this statement.

Regarding their own actions, $61.84 \%$ of the respondents believed that his/her own behavior contributes a lot to a healthy environment, while $56.20 \%$ affirmed that they have a positive attitude and that they feel good when they engage in the e-waste recycling. 


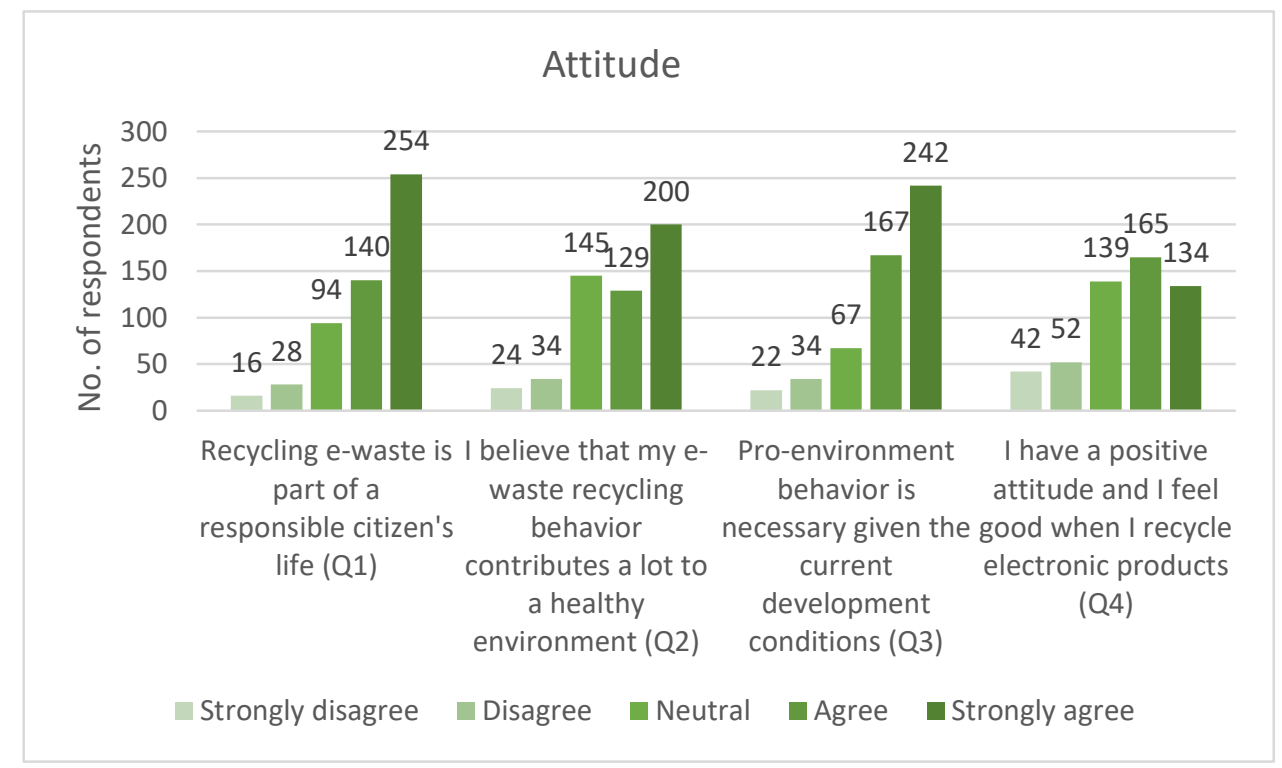

Figure 5. The distribution of the answers received for attitude.

As for the awareness, it was observed that a great part of the respondents knew that the electronic products contain potentially toxic substances $(76.32 \%)$ and that not recycling e-waste can cause environment pollution ( $82.71 \%$ ). Even more, $75.19 \%$ of the respondents were aware of the fact that the way we manage e-waste can harm the human health. A lower percentage of respondents $(47.93 \%)$ were aware of the benefits e-waste recycling can have-Figure 6.

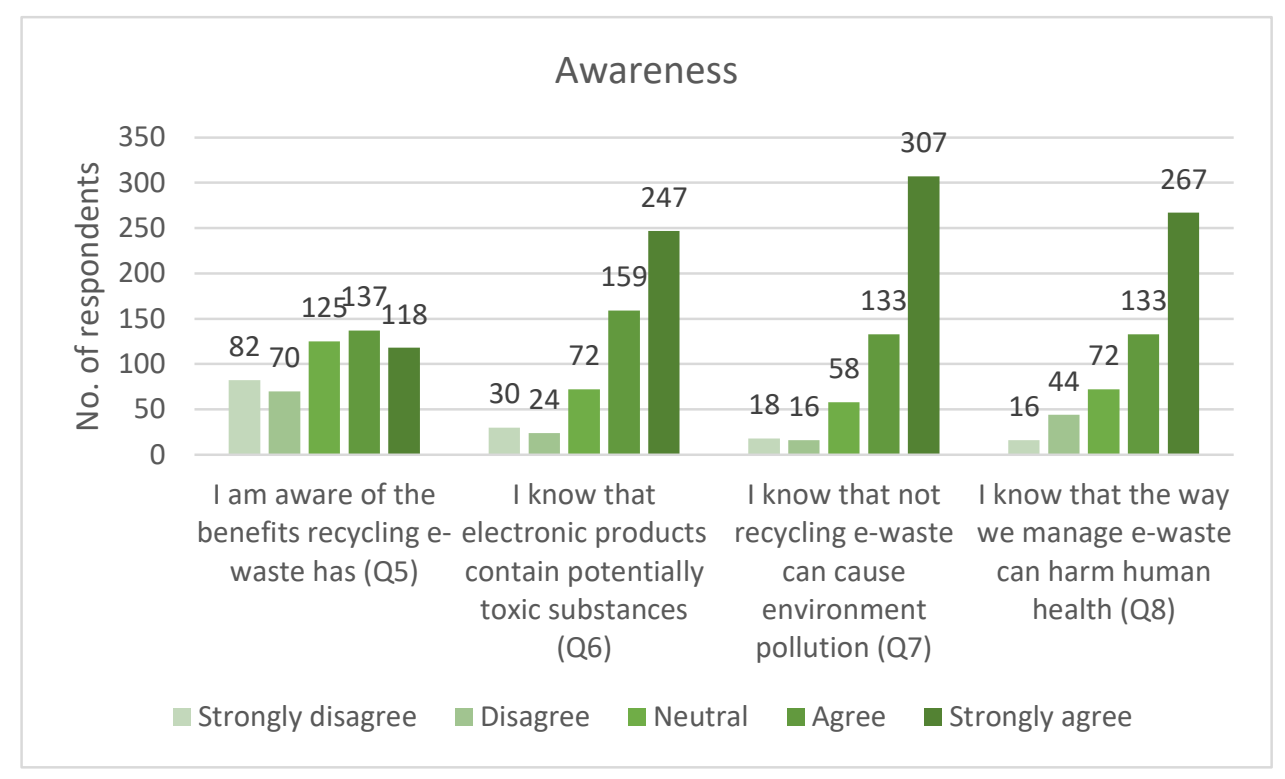

Figure 6. The distribution of the answers received for awareness.

\subsubsection{Self-efficacy and Responsibility in the E-Waste Recycling Context}

Self-efficacy, which reflects an individual's perception regarding his/her ability to perform e-waste-minimizing activities [92], has been measured through the answers received to three questions related to the knowledge associated to the items that can be recycled, to the e-waste recycling centers, and to the easiness to participate in the e-waste recycling activities. The vast majority of the respondents marked "agree" or "strongly agree" on these questions, demonstrating a good self-efficacy level-Table 3. 
As for the responsibility, $77.25 \%$ of the respondents felt responsible to take actions in order to manage the level of e-waste they generate, while $71.79 \%$ of the respondents felt responsible for the environment pollution due to e-waste generation-Table 3.

Table 3. Summary of the answers received for self-efficacy and responsibility.

\begin{tabular}{|c|c|c|c|c|c|c|}
\hline Issue & Questions & $\begin{array}{l}\text { Strongly } \\
\text { Disagree }\end{array}$ & Disagree & Neutral & Agree & Strongly Agree \\
\hline \multirow{3}{*}{ SE } & $\begin{array}{l}\text { I know which are the items that } \\
\text { can be recycled in e-waste } \\
\text { recycling process (Q9) }\end{array}$ & $\begin{array}{c}10 \\
(1.88 \%)\end{array}$ & $\begin{array}{c}16 \\
(3.01 \%)\end{array}$ & $\begin{array}{c}53 \\
(9.96 \%)\end{array}$ & $\begin{array}{c}149 \\
(28.01 \%)\end{array}$ & $\begin{array}{c}304 \\
(57.14 \%)\end{array}$ \\
\hline & $\begin{array}{l}\text { I know where to take my } \\
\text { e-waste for recycling (Q10) }\end{array}$ & $\begin{array}{c}21 \\
(3.95 \%)\end{array}$ & $\begin{array}{c}32 \\
(6.02 \%)\end{array}$ & $\begin{array}{c}86 \\
(16.17 \%)\end{array}$ & $\begin{array}{c}172 \\
(32.33 \%)\end{array}$ & $\begin{array}{c}221 \\
(41.54 \%)\end{array}$ \\
\hline & $\begin{array}{c}\text { I find it easy to participate in } \\
\text { the e-waste recycling } \\
\text { activities (Q11) }\end{array}$ & $\begin{array}{c}20 \\
(3.76 \%)\end{array}$ & $\begin{array}{c}30 \\
(5.64 \%)\end{array}$ & $\begin{array}{c}89 \\
(16.73 \%)\end{array}$ & $\begin{array}{c}178 \\
(33.46 \%)\end{array}$ & $\begin{array}{c}215 \\
(40.41 \%)\end{array}$ \\
\hline \multirow{2}{*}{ RESP } & $\begin{array}{l}\text { I feel responsible to take actions } \\
\text { in order to manage the level of } \\
\text { e-waste I generate (Q12) }\end{array}$ & $\begin{array}{c}12 \\
(2.26 \%)\end{array}$ & $\begin{array}{c}18 \\
(3.38 \%)\end{array}$ & $\begin{array}{c}91 \\
(17.11 \%)\end{array}$ & $\begin{array}{c}170 \\
(31.95 \%)\end{array}$ & $\begin{array}{c}157 \\
(45.30 \%)\end{array}$ \\
\hline & $\begin{array}{l}\text { I feel responsible for the } \\
\text { environment pollution due to } \\
\text { e-waste generation (Q13) }\end{array}$ & $\begin{array}{c}16 \\
(3.01 \%)\end{array}$ & $\begin{array}{c}16 \\
(3.01 \%)\end{array}$ & $\begin{array}{c}117 \\
(21.99 \%)\end{array}$ & $\begin{array}{c}157 \\
(29.51 \%)\end{array}$ & $\begin{array}{c}226 \\
(42.48 \%)\end{array}$ \\
\hline
\end{tabular}

\subsubsection{Social Norms, Social Influence, and Social Media}

Considering the three questions included in the social norms construction, it was observed that, on average, only $23.12 \%$ of the respondents said that their family, friends, and other persons to whom they are in contact expect them to engage in e-waste activities, while $31.58 \%$ have not expressed any opinion regarding this aspect. The vast majority of respondents, $45.30 \%$ of the respondents, marked that their friends, family, and acquaintances do not expect them to engage in e-waste recycling behavior.

As for the social influence, only $27.44 \%$ of the respondents marked that their family, friends, and/or acquaintances talk to them about engaging into e-waste recycling activities, and $25.19 \%$ of respondents said that their friends, families, and other people they interact would appreciate if they engage into e-waste recycling activities. Even more, $32.14 \%$ of the respondents affirmed that the opinion of their family, friends, and other people they interact with regarding e-waste recycling matters to them.

Social media influence was measured through the occurrence of links, discussions, commercials, and videos in the respondents' social media newsfeed-Figure 7. Comparing the answers received on the four categories, it was observed that the highest occurrence was in the links category $(40.04 \%$ of the respondents marked that links related to e-waste appear in their newsfeed), followed by discussions $(33.46 \%)$ and commercials $(32.33 \%)$. Videos represent the category with the smallest amount of appearance, in only $24.06 \%$ of the cases.

Additionally, the degree to which the respondent can be influenced by the posts, videos, links, advertisements, and friends' attitudes on these platforms was extracted-29.14\% of the respondents marked that they can be influenced to a certain extent by other persons' opinions and posts on social media, while $32.71 \%$ affirmed that the videos, advertisements, and the links with information related to the e-waste can make them change their opinion. 


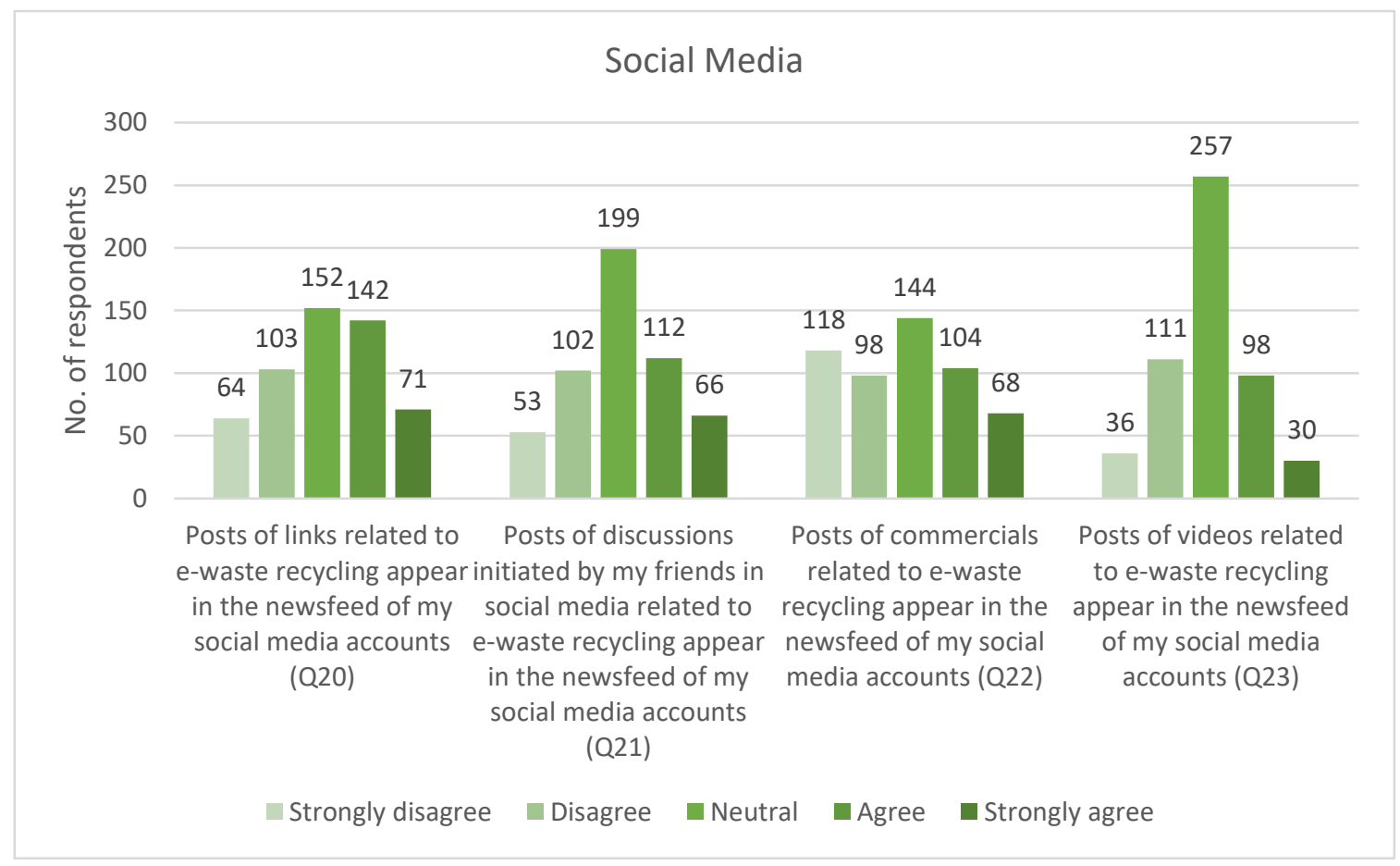

Figure 7. The distribution of the answers received for Social Media.

\subsubsection{Government and NGOs' Actions vs. Government Measures}

Regarding the government's actions, the great majority of the respondents, representing $56.95 \%$, marked that they believe that a program made by the authorities in order to ease the e-waste recycling process would be beneficial, while most of them said that they are not happy with the measures taken by the government for encouraging e-waste collection (56.20\%). Also, NGOs have been seen as the main actors to encourage the e-waste collection process by $51.50 \%$ of the respondents.

As for the government's measures, the opinions were split among the respondents as $31.58 \%$ manifested no opinion, $34.40 \%$ thought that a series of specific laws and enforcements rules would be beneficial, while the rest of $34.02 \%$ disagreed with the introduction of such measures.

\subsubsection{Convenience}

The need for e-waste recycling points was observed in the answers provided by $64.66 \%$ of the respondents, while only $19.36 \%$ of the respondents affirmed that it is easy to find a curbside for e-waste pick-ups.

\subsubsection{Ownership and Knowledge of the E-Waste Products}

The knowledge of the e-waste products was measured by asking the respondents to name some of the electronic devices they have, along with the number of these devices. Based on the received answers, it was observed that all the respondents had the needed knowledge related to identifying the e-waste products, as each respondent named at least one category.

Regarding the ownership of e-waste products, $90.60 \%$ of the respondents named cell phones, followed by television $85.53 \%$, refrigerators $77.26 \%$, computers and laptops $74.81 \%$, kitchen products $50.94 \%$, personal care devices $35.34 \%$, other devices $14.47 \%$.

\subsubsection{E-Waste Recycling Intention and Recycling Behavior}

Recycling intention was measured through the answers received to four questions as presented in Figure 8. Considering the distribution of the answers, it can be observed that, in general, the respondents manifested a good e-waste recycling intention, $63.16 \%$ of them saying that they plan on recycling 
e-waste even though it will not necessarily be easy, $40.79 \%$ plan to participate to e-waste recycling activities advocated on social media, while $56.95 \%$ intend to buy electronic products that can be easily recycled. A percentage of $58.08 \%$ plan to put more effort into the actions related to e-waste recycling process.

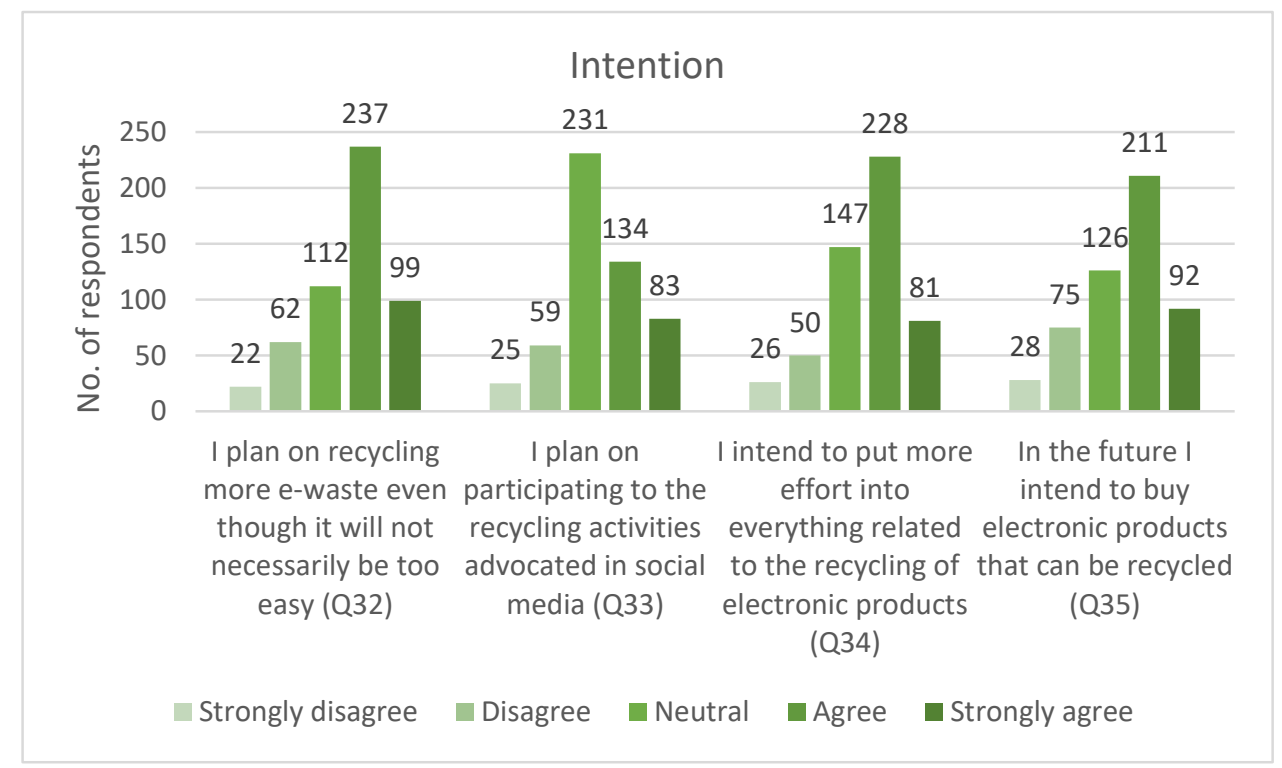

Figure 8. The distribution of the answers received for e-waste recycling intention.

Regarding the recycling of different e-waste products categories, $46.43 \%$ of the respondents mentioned that they have recycled information technology and telecommunications equipment, $41.35 \%$ have recycled consumer equipment, $33.08 \%$ have recycled large household appliances, $26.69 \%$ have recycled small household appliances, while light equipment has been recycled by $18.23 \%$. E-waste not listed in the above categories and included in "other" section has been recycled by $10.53 \%$.

\subsection{Structural Model's Results}

Based on the research hypotheses, the structural modelling was performed. Table 4 summarizes the determined structural path coefficients and the decision taken with regard to each of the formulated hypotheses.

Table 4. Structural path coefficients and hypotheses test results.

\begin{tabular}{cccc}
\hline Hypotheses & Relationship & Structural Path Coefficients & Decision \\
\hline H1 & Attitude -> Intention & $0.277^{* * *}$ & Supported \\
H2 & Awareness - Intention & $0.202^{* *}$ & Supported \\
H3 & Self-efficacy -> Intention & $0.121^{* *}$ & Supported \\
H4 & Responsibility - > Intention & $0.083^{* *}$ & Supported \\
H5 & Social norms -> Intention & $0.075^{*}$ & Supported \\
H6 & Social influence -> Intention & $0.102^{* * *}$ & Supported \\
H7 & Social media - Intention & $0.071^{* *}$ & Supported \\
H8 & Government and NGOs -> Intention & $0.024^{+}$ & Supported \\
H9 & Intention - Behavior & $0.608^{* *}$ & Supported \\
H10 & Government measures -> Behavior & $0.057^{*}$ & Supported \\
H11 & Convenience -> Behavior & $0.026^{+}$ & Supported \\
\hline
\end{tabular}

Note: ${ }^{+} p<0.10,{ }^{*} p<0.05,{ }^{* *} p<0.01,{ }^{* * *} p<0.001$. 
From the data listed in Table 4 it can be seen that all of the hypotheses were supported, but at different levels of significance. Considering the data, it was observed that the factors with significant influence on the e-waste recycling intention were the consumers' attitude and awareness, followed by self-efficacy and social influences. Referring to other studies in the field, the result achieved for the attitude effects on intention was expected $[20,37,42,79,93]$. Also, self-efficacy has been proved in previous studies to have a direct positive influence on consumers' recycling behavior, therefore the outcome has been in line with previous findings from the research literature [20,42]. As for the social influence, Nguyen et al. [42] considered a similar construction named "social pressure" which has been proven to have positive impact on the recycling intention.

Social media, social norms, and responsibility scored positive, but small values in comparison with other factors considered in the model. These findings are in line with the ones provided by Sujata et al. [20] in their study, which underlined the fact that social media appeared to be a weak predictor of intention.

Last, government and NGOs' actions seems to have little influence on consumers' intention to recycle, this being a possible consequence of the reduced activity carried on by these organizations.

As for the elements influencing the consumers' behavior to engage in e-waste recycling processes, the main trigger was found to be the e-waste recycling intention. The results obtained a high level of significance. Even in this case the results were consistent with past studies from the research literature [20,94-96]. Government measures seemed to have a small direct positive effect on the recycling decision, while convenience exerted even a smaller effect.

\subsection{Contribution of Demographic Variables}

Demographic or socio-economic variables have shown over the time to have a contribution to predicting the consumers' pro-recycling behavior. The opinions related to which of the demographic or socio-economic factors have an impact on the recycling behavior have been divided in the literature.

For example, age was one of the most discussed aspects for which no mutual agreement has been reached. A series of researchers believed that age has a contribution to recycling [77,97-102], most of them underlying the fact that seniors are more prone to recycling actions, while others did not find any connection between recycling and age [42,103-105].

Gender was another demographic variable considered in the research literature. While most of the researchers found a connection between gender and recycling, stating that women showed more readiness to recycle than men $[42,102,106,107]$, there are also studies proving the contrary $[105,108,109]$. Even more, Darby and Obara [110] found that for US consumers, men were more likely to visit the CA sites, while Arcury et al. [111] suggested that women are usually associated to this process as traditionally they play an important role in every household's domestic activities.

Other demographic and socio-economic variables considered to influence the recycling decisions have been: education level [77,102,112], family size [77,107,112,113], income [77,98,103,110,112,113], ethnicity $[107,114]$, and residence type [115].

Additionally, Husmann et al. [116] believed that the discrepancies in the findings of different studies can be due to culture in various countries.

As a result, in the present study we considered all the demographic and socio-economic variables extracted through the questionnaire. After running the structural equations analysis, differences were found among different categories based on only gender and age. These differences are presented and discussed below.

\subsubsection{Gender Contribution}

The relationship between attitude, awareness, self-efficacy, social influence, and social media seems to have a significant positive impact on e-waste recycling intention for both male and female respondents-Table 5. Compared to females, males showed a higher effect of awareness and self-efficacy on the intention, while females' attitude had a higher effect on intention. Social media influence was 
slightly higher in the case of female respondents, while social influence seemed to have a higher influence in the case of the male respondents.

Also, responsibility and social norms were significant only in the case of females, while the government and NGOs' actions seemed to be significant in the case of the male persons.

Regarding the e-waste recycling behavior, intention was the main trigger in the case of both male and female participants in the study, with higher values scored in the case of men. At the same time, convenience and government measures scored positive for the e-waste recycling behavior only in the case of male respondents.

Table 5. Structural path coefficients and hypotheses test results based on gender.

\begin{tabular}{|c|c|c|c|c|}
\hline \multirow{2}{*}{ Hypotheses } & \multirow{2}{*}{ Relationship } & \multicolumn{2}{|c|}{ Structural Path Coefficients } & \multirow{2}{*}{ Significance } \\
\hline & & Female & Male & \\
\hline $\mathrm{H} 1$ & Attitude -> Intention & $0.307^{* * *}$ & $0.261^{* *}$ & Both \\
\hline $\mathrm{H} 2$ & Awareness -> Intention & $0.147 *$ & $0.198^{* *}$ & Both \\
\hline $\mathrm{H} 3$ & Self-efficacy $->$ Intention & $0.063 *$ & $0.156^{* * *}$ & Both \\
\hline $\mathrm{H} 4$ & Responsibility -> Intention & $0.104^{* *}$ & 0.031 & Female \\
\hline H5 & Social norms -> Intention & $0.095^{*}$ & 0.061 & Female \\
\hline H6 & Social influence -> Intention & $0.098^{* *}$ & $0.087^{* *}$ & Both \\
\hline H7 & Social media -> Intention & $0.064^{* *}$ & 0.070 * & Both \\
\hline H8 & Government and NGOs -> Intention & 0.011 & 0.032 * & Male \\
\hline H9 & Intention -> Behavior & $0.549^{* *}$ & $0.606^{* * *}$ & Both \\
\hline $\mathrm{H} 10$ & Government measures -> Behavior & 0.029 & $0.063^{* *}$ & Male \\
\hline H11 & Convenience -> Behavior & 0.014 & 0.057 * & Male \\
\hline
\end{tabular}

\subsubsection{Age Contribution}

Based on age, it was observed that all the three considered categories $(\leq 30 ; 30-50 ; \geq 50)$ manifested an effect of attitude, awareness, and social influence on the e-waste recycling behavior-Table 6 . Higher values were reported for the "30-50" category in terms of the influence of awareness on e-waste recycling intention when compared to the other two age categories.

Responsibility and social norms were important factors in e-waste recycling behavior for persons in the " $30-50$ " and " $\geq 50$ " age categories, while social media influence manifested more in the cases of the " $\leq 30$ " and "30-50" categories. Also, the government and NGOs' actions seemed to have an influence in the case of the persons in the " $\leq 30$ " category.

The influence of intention on e-waste recycling behavior was observed in all the three categories under investigation, with high values in the case of " $\geq 50$ " category. Even more, the government measures seemed to have an effect on the recycling decision only in the case of the " $\geq 50$ " category, while convenience scored relevant values for the recycling behavior in the case of the "30-50" category. 
Table 6. Structural path coefficients and hypotheses test results based on age.

\begin{tabular}{|c|c|c|c|c|c|}
\hline \multirow{2}{*}{ Hypotheses } & \multirow{2}{*}{ Relationship } & \multicolumn{3}{|c|}{ Structural Path Coefficients } & \multirow{2}{*}{ Significance } \\
\hline & & $\leq 30$ & $30-50$ & $\geq 50$ & \\
\hline $\mathrm{H} 1$ & Attitude -> Intention & $0.251 *$ & $0.284^{* * *}$ & $0.265 *$ & All \\
\hline $\mathrm{H} 2$ & Awareness -> Intention & $0.174^{* *}$ & $0.222 *$ & 0.180 * & All \\
\hline H3 & Self-efficacy -> Intention & $0.147 *$ & 0.104 & 0.087 & $\leq 30$ \\
\hline $\mathrm{H} 4$ & Responsibility -> Intention & 0.033 & $0.091 * *$ & $0.102 *$ & $30-50 ; \geq 50$ \\
\hline H5 & Social norms -> Intention & 0.062 & $0.094^{* *}$ & $0.091 *$ & $30-50 ; \geq 50$ \\
\hline H6 & Social influence -> Intention & $0.134^{* * *}$ & $0.097^{* *}$ & $0.083 *$ & All \\
\hline H7 & Social media -> Intention & $0.088^{* * *}$ & 0.064 * & 0.049 & $\leq 30 ; 30-50$ \\
\hline $\mathrm{H} 8$ & Government and NGOs -> Intention & $0.042 *$ & 0.011 & 0.008 & $\leq 30$ \\
\hline H9 & Intention $->$ Behavior & $0.583^{* *}$ & $0.596^{* *}$ & $0.611^{* * *}$ & All \\
\hline $\mathrm{H} 10$ & Government measures -> Behavior & 0.040 & 0.063 & $0.059 *$ & $\geq 50$ \\
\hline H11 & Convenience $->$ Behavior & 0.019 & $0.031 *$ & 0.024 & $30-50$ \\
\hline
\end{tabular}

Note: ${ }^{*} p<0.05,{ }^{* *} p<0.01,{ }^{* * *} p<0.001$.

\section{Conclusions}

The present paper tried to model the potential influence of various determinants on e-waste recycling intention and behavior. The need for this study exists both in the context of highly generated amounts of e-waste every year, but also due to the different influences the determinant factors can have over the decision variables.

The study focused on some of the elements already stated in the literature as main determinants for the e-waste recycling intention and decisions, while adding some new factors that emerged from the occurrence and high use of the social media environments. Also, the activity conducted by the government was captured by splitting the activity made by the organization into actions and measures. While government actions have been assumed to influence the consumers' e-waste recycling intention, the government measures have been assumed to have a direct impact on the consumers' final behavior in relation with the recycling decision. Beside the government, the actions carried on the by the NGOs have been assumed to have an impact on the e-waste recycling intention.

For capturing all the dimensions related to the determinant factors, a questionnaire was created and validated. A structural equation model was used for analyzing this complex situation.

Even more, the demographic and socio-economic variables were analyzed as, in the research literature, there was no common ground regarding their influence on the e-waste recycling behavior.

Among the findings, the positive effect of all the considered variables on the e-waste recycling intention can be underlined. The analysis revealed that attitude and awareness towards e-waste recycling were the primary influencing factors for the intention to recycle, which underlines more the need for campaigns that contribute to increasing people's understanding over the harmful influence on environmental and human health.

Also, the self-efficacy and social influence have a contribution to the e-waste recycling intention, which makes us believe that the campaigns must be designed based on an educative ground that will make consumers better understand which are the items to be recycled and what are the needed steps to be taken for recycling, making this process as easy as possible. As for the social influence, the increase in knowledge related to this phenomenon might enhance the diffusion system of information among various participants to the economic life, including families, friends, and acquaintances, with a direct result on the increase in e-waste recycling intention.

Even other determinant factors that scored positive but smaller values, such as social media and social norms, can make their contribution through a proper communication program related to the e-waste recycling process. Considering the high amount of time spent on social media, some campaigns designed especially for diffusion in this environment can encourage consumers' to participate in the recycling process. 
Boosting the consumers' intention has been proven to have a direct and positive impact on their e-waste recycling behavior. Government measures and convenience scored lesser, but positive, scores, which shows that there is still a place for changes in these determinant factors.

Nevertheless, the analysis provided, featuring the gender and age demographic variables' contribution to boosting the recycling intention and decision, has showed that a more in-depth analysis can provide additional information related to the determinant factors for each of the considered categories. Even though the main determinants have remained the same among the selected categories, the secondary determinant factors can offer more insight to the policy-makers on the channels they can use and the actions they can take in order to boost the e-waste recycling behavior.

The study has its limitations, given by the size of the sample, the fact that it only contained respondents that used social media, and by the specificity, as it applied to Romanian citizens.

In order to better shape the interactions among the consumers, the study was aimed to be extended by including the results gathered from the questionnaire in an agent-based model. By creating intelligent agents that act similarly to real persons engaged in the recycling process, the behavior of the consumers can be better analyzed and the outcome can be more easily observed when little changes are made to the input variables. Also, combined effects can be easier to observe in an agent-based environment.

Author Contributions: Conceptualization, C.D. and L.C.; data curation, C.D. and L.-A.C.; formal analysis, C.D. and G.F.; investigation, G.F. and L.-A.C.; methodology, C.D. and L.-A.C.; software, G.F. and L.-A.C.; supervision, C.D.; validation, L.C. and C.I.; visualization, L.C. and C.I.; writing-original draft, C.D.; writing-review and editing, C.I., G.F., and L.-A.C. All authors have read and agreed to the published version of the manuscript.

Funding: This research received no external funding.

Acknowledgments: The results included in this work are part of the project FutureWeb, supported by the Romanian Ministry of Research and Innovation, CCCDI-UEFISCDI, project number PN-III-P1-1.2-PCCDI-2017-0800/86PCCDI/2018-FutureWeb, within PNCD III.

Conflicts of Interest: The authors declare no conflict of interest.

Appendix A

Table A1. Research questionnaire.

\begin{tabular}{|c|c|c|c|c|c|c|c|}
\hline Issue & Acronym & Questions & 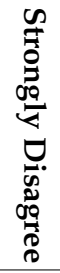 & 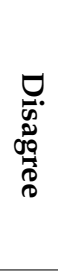 & $\begin{array}{l}Z \\
\mathbf{Z} \\
\stackrel{0}{0} \\
\underline{0}\end{array}$ & $\underset{\substack{D \\
0 \\
0 \\
0}}{0}$ & 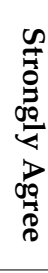 \\
\hline \multirow{4}{*}{ Attitude } & \multirow{4}{*}{ AT } & $\begin{array}{c}\text { Recycling e-waste is part of a responsible } \\
\text { citizen's life (Q1) }\end{array}$ & $\square$ & $\square$ & $\square$ & $\square$ & $\square$ \\
\hline & & $\begin{array}{l}\text { I believe that my e-waste recycling behavior } \\
\text { contributes a lot to a healthy environment (Q2) }\end{array}$ & $\square$ & $\square$ & $\square$ & $\square$ & $\square$ \\
\hline & & $\begin{array}{l}\text { Pro-environment behavior is necessary given } \\
\text { the current development conditions (Q3) }\end{array}$ & $\square$ & $\square$ & $\square$ & $\square$ & $\square$ \\
\hline & & $\begin{array}{l}\text { I have a positive attitude and I feel good when I } \\
\text { recycle electronic products (Q4) }\end{array}$ & $\square$ & $\square$ & $\square$ & $\square$ & $\square$ \\
\hline
\end{tabular}


Table A1. Cont.

\begin{tabular}{|c|c|c|c|c|c|c|c|}
\hline Issue & Acronym & Questions & 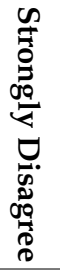 & 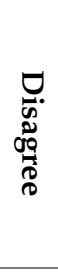 & 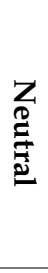 & 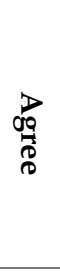 & 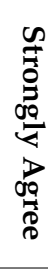 \\
\hline \multirow{4}{*}{ Awareness } & \multirow{4}{*}{$\mathrm{AW}$} & $\begin{array}{c}\text { I am aware of the benefits recycling e-waste } \\
\text { has (Q5) }\end{array}$ & $\square$ & $\square$ & $\square$ & $\square$ & $\square$ \\
\hline & & $\begin{array}{l}\text { I know that electronic products contain } \\
\text { potentially toxic substances }(\mathrm{Q} 6)\end{array}$ & $\square$ & $\square$ & $\square$ & $\square$ & $\square$ \\
\hline & & $\begin{array}{c}\text { I know that not recycling e-waste can cause } \\
\text { environment pollution (Q7) }\end{array}$ & $\square$ & $\square$ & $\square$ & $\square$ & $\square$ \\
\hline & & $\begin{array}{l}\text { I know that the way we manage e-waste can } \\
\text { harm human health (Q8) }\end{array}$ & $\square$ & $\square$ & $\square$ & $\square$ & $\square$ \\
\hline \multirow{3}{*}{ Self-efficacy } & \multirow{3}{*}{ SE } & $\begin{array}{c}\text { I know which are the items that can be recycled } \\
\text { in e-waste recycling process (Q9) }\end{array}$ & $\square$ & $\square$ & $\square$ & $\square$ & $\square$ \\
\hline & & $\begin{array}{l}\text { I know where to take my e-waste for } \\
\text { recycling (Q10) }\end{array}$ & $\square$ & $\square$ & $\square$ & $\square$ & $\square$ \\
\hline & & $\begin{array}{l}\text { I find it easy to participate in the e-waste } \\
\text { recycling activities (Q11) }\end{array}$ & $\square$ & $\square$ & $\square$ & $\square$ & $\square$ \\
\hline \multirow{2}{*}{ Responsibility } & \multirow{2}{*}{ RESP } & $\begin{array}{l}\text { I feel responsible to take actions in order to } \\
\text { manage the level of e-waste I generate (Q12) }\end{array}$ & $\square$ & $\square$ & $\square$ & $\square$ & $\square$ \\
\hline & & $\begin{array}{l}\text { I feel responsible for the environment pollution } \\
\text { due e-waste generation (Q13) }\end{array}$ & $\square$ & $\square$ & $\square$ & $\square$ & $\square$ \\
\hline \multirow{3}{*}{ Social Norms } & \multirow{3}{*}{ SN } & $\begin{array}{l}\text { My family expect me to engage in e-waste } \\
\text { recycling behavior (Q14) }\end{array}$ & $\square$ & $\square$ & $\square$ & $\square$ & $\square$ \\
\hline & & $\begin{array}{l}\text { My friends expect me to engage in e-waste } \\
\text { recycling behavior (Q15) }\end{array}$ & $\square$ & $\square$ & $\square$ & $\square$ & $\square$ \\
\hline & & $\begin{array}{c}\text { Other persons with whom I am in contact } \\
\text { expect me to engage in e-waste recycling } \\
\text { behavior (Q16) }\end{array}$ & $\square$ & $\square$ & $\square$ & $\square$ & $\square$ \\
\hline \multirow{3}{*}{ Social Influence } & \multirow{3}{*}{ SI } & $\begin{array}{l}\text { Family/friends/people around me talk about } \\
\text { e-waste recycling and/or recommend me to } \\
\text { engage in e-waste recycling (Q17) }\end{array}$ & $\square$ & $\square$ & $\square$ & $\square$ & $\square$ \\
\hline & & $\begin{array}{c}\text { Family/friends/people around me would } \\
\text { appreciate if I engage in an e-waste recycling } \\
\text { behavior (Q18) }\end{array}$ & $\square$ & $\square$ & $\square$ & $\square$ & $\square$ \\
\hline & & $\begin{array}{l}\text { The opinions of family/friends/people around } \\
\text { regarding e-waste recycling matters to me (Q19) }\end{array}$ & $\square$ & $\square$ & $\square$ & $\square$ & $\square$ \\
\hline
\end{tabular}


Table A1. Cont.

\begin{tabular}{|c|c|c|c|c|c|c|c|}
\hline Issue & Acronym & Questions & 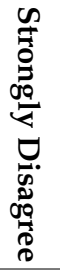 & 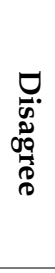 & 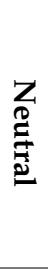 & 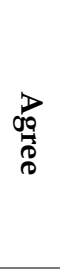 & 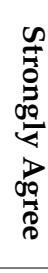 \\
\hline \multirow{4}{*}{ Social Media } & \multirow{4}{*}{ SM } & $\begin{array}{c}\text { Posts of links related to e-waste recycling } \\
\text { appear in the newsfeed of my social media } \\
\text { accounts (Q20) }\end{array}$ & $\square$ & $\square$ & $\square$ & $\square$ & $\square$ \\
\hline & & $\begin{array}{c}\text { Posts of discussions initiated by my friends on } \\
\text { social media related to e-waste recycling appear } \\
\text { in the newsfeed of my social media } \\
\text { accounts (Q21) }\end{array}$ & $\square$ & $\square$ & $\square$ & $\square$ & $\square$ \\
\hline & & $\begin{array}{l}\text { Posts of commercials related to e-waste } \\
\text { recycling appear in the newsfeed of my social } \\
\text { media accounts }(\mathrm{Q} 22)\end{array}$ & $\square$ & $\square$ & $\square$ & $\square$ & $\square$ \\
\hline & & $\begin{array}{l}\text { Posts of videos related to e-waste recycling } \\
\text { appear in the newsfeed of my social media } \\
\text { accounts (Q23) }\end{array}$ & $\square$ & $\square$ & $\square$ & $\square$ & $\square$ \\
\hline \multirow{4}{*}{$\begin{array}{l}\text { Government } \\
\text { and NGOs }\end{array}$} & \multirow{4}{*}{ GNGO } & $\begin{array}{c}\text { The actions made by the government and/or } \\
\text { NGOs for encouraging e-waste collection makes } \\
\text { me happy (Q24) }\end{array}$ & $\square$ & $\square$ & $\square$ & $\square$ & $\square$ \\
\hline & & $\begin{array}{l}\text { The services offered by the government ease the } \\
\text { e-waste recycling process (Q25) }\end{array}$ & $\square$ & $\square$ & $\square$ & $\square$ & $\square$ \\
\hline & & $\begin{array}{l}\text { NGOs are one of the main actors that encourage } \\
\text { the e-waste recycling process (Q26) }\end{array}$ & $\square$ & $\square$ & $\square$ & $\square$ & $\square$ \\
\hline & & $\begin{array}{l}\text { A program by the authorities for collecting } \\
\text { electronic products for recycling from people's } \\
\text { houses would be useful (Q27) }\end{array}$ & $\square$ & $\square$ & $\square$ & $\square$ & $\square$ \\
\hline \multirow{2}{*}{ Convenience } & \multirow{2}{*}{ CONV } & $\begin{array}{l}\text { Near my house there are many recycling centers } \\
\text { for electronic products }(\mathrm{Q} 28)\end{array}$ & $\square$ & $\square$ & $\square$ & $\square$ & $\square$ \\
\hline & & $\begin{array}{l}\text { I found it to be easy and convenient to access } \\
\text { the curbside pick-ups for the e-waste (Q29) }\end{array}$ & $\square$ & $\square$ & $\square$ & $\square$ & $\square$ \\
\hline \multirow{2}{*}{$\begin{array}{l}\text { Government } \\
\text { Measures }\end{array}$} & \multirow{2}{*}{ GM } & $\begin{array}{l}\text { Some specific laws on the recycling of electronic } \\
\text { products would make me recycle more (Q30) }\end{array}$ & $\square$ & $\square$ & $\square$ & $\square$ & $\square$ \\
\hline & & $\begin{array}{l}\text { I believe that if the government enforced the } \\
\text { rules for e-waste more electronics product will } \\
\text { be recycled (Q31) }\end{array}$ & $\square$ & $\square$ & $\square$ & $\square$ & $\square$ \\
\hline \multirow{4}{*}{$\begin{array}{l}\text { Recycling } \\
\text { Intention }\end{array}$} & \multirow{4}{*}{ RI } & $\begin{array}{l}\text { I plan on recycling more e-waste even though it } \\
\text { will not necessarily be too easy (Q32) }\end{array}$ & $\square$ & $\square$ & $\square$ & $\square$ & $\square$ \\
\hline & & $\begin{array}{c}\text { I plan on participating in the recycling activities } \\
\text { advocated in social media (Q33) }\end{array}$ & $\square$ & $\square$ & $\square$ & $\square$ & $\square$ \\
\hline & & $\begin{array}{l}\text { I intend to put more effort into everything } \\
\text { related to the recycling of electronic } \\
\text { products (Q34) }\end{array}$ & $\square$ & $\square$ & $\square$ & $\square$ & $\square$ \\
\hline & & $\begin{array}{l}\text { In the future I intend to buy electronic products } \\
\text { that can be recycled (Q35) }\end{array}$ & $\square$ & $\square$ & $\square$ & $\square$ & $\square$ \\
\hline
\end{tabular}


Table A1. Cont.

\begin{tabular}{|c|c|c|c|c|c|c|c|}
\hline Issue & Acronym & Questions & 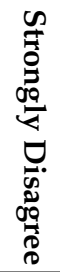 & 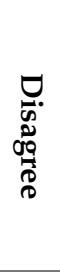 & 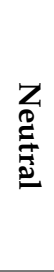 & $\underset{\substack{D \\
0 \\
0}}{\substack{0 \\
0}}$ & 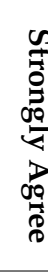 \\
\hline \multirow{6}{*}{$\begin{array}{l}\text { Recycling } \\
\text { Behavior }\end{array}$} & \multirow{6}{*}{$\mathrm{RB}$} & $\begin{array}{l}\text { I recycle large household appliances } \\
\text { (e.g., washing machines, dishwashers, } \\
\text { air conditioners, refrigerators, } \\
\text { microwaves, etc.) (Q36) }\end{array}$ & $\square$ & $\square$ & $\square$ & $\square$ & $\square$ \\
\hline & & $\begin{array}{l}\text { I recycle small household appliances } \\
\text { (e.g., toasters, vacuum cleaners, coffee machines, } \\
\text { appliances for toothbrushing, shaving, } \\
\text { hair drying, etc.) (Q37) }\end{array}$ & $\square$ & $\square$ & $\square$ & $\square$ & $\square$ \\
\hline & & $\begin{array}{c}\text { I recycle information technology and } \\
\text { telecommunications equipment (e.g., laptops, } \\
\text { personal computers, notebooks, telephones, cell } \\
\text { phones, printers, etc.) (Q38) }\end{array}$ & $\square$ & $\square$ & $\square$ & $\square$ & $\square$ \\
\hline & & $\begin{array}{l}\text { I recycle consumer equipment (e.g., video } \\
\text { recorders, stereo recorders, musical instruments, } \\
\text { radios, televisions, etc.) (Q39) }\end{array}$ & $\square$ & $\square$ & $\square$ & $\square$ & $\square$ \\
\hline & & I recycle light equipment (Q40) & $\square$ & $\square$ & $\square$ & $\square$ & $\square$ \\
\hline & & $\begin{array}{l}\text { I recycle other categories of e-waste (not listed } \\
\text { above, e.g., electronical and electronic tools, } \\
\text { leisure equipment, medical devices, monitoring } \\
\text { and control instruments, automatic dispensers, } \\
\text { etc.) (Q41) }\end{array}$ & $\square$ & $\square$ & $\square$ & $\square$ & $\square$ \\
\hline
\end{tabular}

\section{References}

1. Gill, G.N. Electronic Waste. Available online: https://www.britannica.com/technology/electronic-waste (accessed on 4 March 2020).

2. LeBlanc, R. Learn More about E-Waste Recycling with These Facts and Figures. Available online: https: //www.thebalancesmb.com/e-waste-recycling-facts-and-figures-2878189 (accessed on 4 March 2020).

3. Blade, C.P.; Forti, V.; Gray, V.; Kuehr, R.; Stegmann, P. The Global E-Waste Monitor. 2017. Available online: https://www.itu.int/en/ITUD/Climate-Change/Documents/GEM\%202017/Global-E-waste\% 20Monitor\%202017\%20.pdf (accessed on 22 February 2019).

4. Eurostat Statistics Eurostat. Available online: https://ec.europa.eu/eurostat/databrowser/view/cei_wm050/ default/table?lang=en (accessed on 4 March 2019).

5. Huisman, J.; Leroy, P.; Tertre, F.; Söderman, M.L.; Chancerel, P.; Cassard, D.; Løvik, A.N.; Wäger, P.; Kushnir, D.; Rotter, V.S.; et al. Prospecting Secondary Raw Materials in the Urban Mine and Mining Wastes (ProSUM). Available online: http://prosumproject.eu/sites/default/files/DIGITAL_Final_Report.pdf (accessed on 4 March 2019).

6. The World Counts. Electronic Waste Facts. Available online: https://www.theworldcounts.com/stories/ Electronic-Waste-Facts (accessed on 4 February 2020).

7. Blake, V.; Farrelly, T.; Hannon, J. Is Voluntary Product Stewardship for E-Waste Working in New Zealand? A Whangarei Case Study. Sustainability 2019, 11, 3063. [CrossRef]

8. Jaiswal, A.; Samuel, C.; Patel, B.S.; Kumar, M. Go Green with WEEE: Eco-friendly Approach for Handling E-waste. Procedia Comput. Sci. 2015, 46, 1317-1324. [CrossRef]

9. Kiddee, P.; Naidu, R.; Wong, M.H. Electronic waste management approaches: An overview. Waste Manag. 2013, 33, 1237-1250. [CrossRef] [PubMed] 
10. Robinson, B.H. E-waste: An assessment of global production and environmental impacts. Sci. Total Environ. 2009, 408, 183-191. [CrossRef]

11. Shevchenko, T.; Laitala, K.; Danko, Y. Understanding Consumer E-Waste Recycling Behavior: Introducing a New Economic Incentive to Increase the Collection Rates. Sustainability 2019, 11, 2656. [CrossRef]

12. El-Mously, H. Innovating green products as a mean to alleviate poverty in Upper Egypt. Ain Shams Eng. J. 2018, 9, 2039-2056. [CrossRef]

13. De Medeiros, J.F.; Ribeiro, J.L.D. Environmentally sustainable innovation: Expected attributes in the purchase of green products. J. Clean. Prod. 2017, 142, 240-248. [CrossRef]

14. Zhang, W.; He, Y. Optimal policies for new and green remanufactured short-life-cycle products considering consumer behavior. J. Clean. Prod. 2019, 214, 483-505. [CrossRef]

15. Dobrowolski, J.W.; Bedla, D.; Czech, T.; Gambuś, F.; Górecka, K.; Kiszczak, W.; Kuźniar, T.; Mazur, R.; Nowak, A.; Śliwka, M.; et al. Integrated Innovative Biotechnology for Optimization of Environmental Bioprocesses and a Green Economy. In Optimization and Applicability of Bioprocesses; Purohit, H.J., Kalia, V.C., Vaidya, A.N., Khardenavis, A.A., Eds.; Springer: Singapore, 2017; pp. 27-71. ISBN 978-981-10-6863-8.

16. D'Adamo, I. Adopting a Circular Economy: Current Practices and Future Perspectives. Soc. Sci. 2019, 8, 328. [CrossRef]

17. Liu, X.; Tanaka, M.; Matsui, Y. Electrical and electronic waste management in China: Progress and the barriers to overcome. Waste Manag. Res. 2006, 24, 92-101. [CrossRef]

18. Wang, W.; Tian, Y.; Zhu, Q.; Zhong, Y. Barriers for household e-waste collection in China: Perspectives from formal collecting enterprises in Liaoning Province. J. Clean. Prod. 2017, 153, 299-308. [CrossRef]

19. Miner, K.J.; Rampedi, I.T.; Ifegbesan, A.P.; Machete, F. Survey on Household Awareness and Willingness to Participate in E-Waste Management in Jos, Plateau State, Nigeria. Sustainability 2020, 12, 1047. [CrossRef]

20. Sujata, M.; Khor, K.-S.; Ramayah, T.; Teoh, A.P. The role of social media on recycling behaviour. Sustain. Prod. Consum. 2019, 20,365-374. [CrossRef]

21. Statista. Social Media Penetration Rate Worldwide. 2019. Available online: https://www.statista.com/ statistics/269615/social-network-penetration-by-region/ (accessed on 5 March 2020).

22. Rodrigues, A.C.; Boscov, M.E.G.; Günther, W.M.R. Domestic flow of e-waste in São Paulo, Brazil: Characterization to support public policies. Waste Manag. 2020, 102, 474-485. [CrossRef]

23. Kumar, A.; Holuszko, M. Electronic Waste and Existing Processing Routes: A Canadian Perspective. Resources 2016, 5, 35. [CrossRef]

24. Wong, N.W.M. Electronic Waste Governance under "One Country, Two Systems": Hong Kong and Mainland China. Int. J. Environ. Res. Public Health 2018, 15, 2347. [CrossRef]

25. Steuer, B. What Institutional Dynamics Guide Waste Electrical and Electronic Equipment Refurbishment and Reuse in Urban China? Recycling 2016, 1, 286. [CrossRef]

26. Lee, S.; Na, S. E-Waste Recycling Systems and Sound Circulative Economies in East Asia: A Comparative Analysis of Systems in Japan, South Korea, China and Taiwan. Sustainability 2010, 2, 1632-1644. [CrossRef]

27. Xue, R.; Zhang, F.; Tian, F. A System Dynamics Model to Evaluate Effects of Retailer-Led Recycling Based on Dual Chains Competition: A Case of e-Waste in China. Sustainability 2018, 10, 3391. [CrossRef]

28. Wang, Z.; Wang, Q.; Chen, B.; Wang, Y. Evolutionary game analysis on behavioral strategies of multiple stakeholders in E-waste recycling industry. Resour. Conserv. Recycl. 2020, 155, 104618. [CrossRef]

29. Abarca-Guerrero, L.; Roa-Gutiérrez, F.; Rudín-Vega, V. WEEE Resource Management System in Costa Rica. Resources 2018, 7, 2. [CrossRef]

30. Daum, K.; Stoler, J.; Grant, R.J. Toward a More Sustainable Trajectory for E-Waste Policy: A Review of a Decade of E-Waste Research in Accra, Ghana. Int. J. Environ. Res. Public Health 2017, 14, 135. [CrossRef] [PubMed]

31. Asante, K.A.; Agusa, T.; Biney, C.A.; Agyekum, W.A.; Bello, M.; Otsuka, M.; Itai, T.; Takahashi, S.; Tanabe, S. Multi-trace element levels and arsenic speciation in urine of e-waste recycling workers from Agbogbloshie, Accra in Ghana. Sci. Total Environ. 2012, 424, 63-73. [CrossRef] [PubMed]

32. Aidonis, D.; Achillas, C.; Folinas, D.; Keramydas, C.; Tsolakis, N. Decision Support Model for Evaluating Alternative Waste Electrical and Electronic Equipment Management Schemes-A Case Study. Sustainability 2019, 11, 3364. [CrossRef]

33. Radulovic, V. Portrayals in Print: Media Depictions of the Informal Sector's Involvement in Managing E-Waste in India. Sustainability 2018, 10, 966. [CrossRef] 
34. Isernia, R.; Passaro, R.; Quinto, I.; Thomas, A. The Reverse Supply Chain of the E-Waste Management Processes in a Circular Economy Framework: Evidence from Italy. Sustainability 2019, 11, 2430. [CrossRef]

35. Cruz-Sotelo, S.E.; Ojeda-Benítez, S.; Jáuregui Sesma, J.; Velázquez-Victorica, K.I.; Santillán-Soto, N.; García-Cueto, O.R.; Alcántara Concepción, V.; Alcántara, C. E-Waste Supply Chain in Mexico: Challenges and Opportunities for Sustainable Management. Sustainability 2017, 9, 503. [CrossRef]

36. Cordova-Pizarro, D.; Aguilar-Barajas, I.; Romero, D.; Rodriguez, C.A. Circular Economy in the Electronic Products Sector: Material Flow Analysis and Economic Impact of Cellphone E-Waste in Mexico. Sustainability 2019, 11, 1361. [CrossRef]

37. Nduneseokwu, C.; Qu, Y.; Appolloni, A. Factors Influencing Consumers' Intentions to Participate in a Formal E-Waste Collection System: A Case Study of Onitsha, Nigeria. Sustainability 2017, 9, 881. [CrossRef]

38. Gunarathne, N.; de Alwis, A.; Alahakoon, Y. Challenges facing sustainable urban mining in the e-waste recycling industry in Sri Lanka. J. Clean. Prod. 2020, 251, 119641. [CrossRef]

39. Cheng, C.; Lin, C.; Wen, L.; Chang, T. Determining Environmental Costs: A Challenge in a Governmental E-Waste Recycling Scheme. Sustainability 2019, 11, 5156. [CrossRef]

40. Tonglet, M.; Phillips, P.S.; Read, A.D. Using the Theory of Planned Behaviour to investigate the determinants of recycling behaviour: A case study from Brixworth, UK. Resour. Conserv. Recycl. 2004, 41, 191-214. [CrossRef]

41. Kahhat, R.; Kim, J.; Xu, M.; Allenby, B.; Williams, E.; Zhang, P. Exploring e-waste management systems in the United States. Resour. Conserv. Recycl. 2008, 52, 955-964. [CrossRef]

42. Thi Thu Nguyen, H.; Hung, R.-J.; Lee, C.-H.; Thi Thu Nguyen, H. Determinants of Residents' E-Waste Recycling Behavioral Intention: A Case Study from Vietnam. Sustainability 2019, 11, 164. [CrossRef]

43. Pãcesilã, M.; Ciocoiu, C.; Colesca, S.E.; Burcea, S. Current Trends in WEEE Management in Romania. Theor. Empir. Res. Urban Manag. 2016, 11, 46-60.

44. Eurostat Waste Statistics. Electrical and Electronic Equipment-Statistics Explained. Available online: https://ec.europa.eu/eurostat/statistics-explained/index.php?title=Waste_statistics_-_electrical_and_ electronic_equipment\&oldid=470242 (accessed on 8 March 2020).

45. Urban Mine Platform. Waste Generated. Available online: http://www.urbanmineplatform.eu/urbanmine/ eee/weightpercapita (accessed on 8 February 2020).

46. Lakatos, E.; Cioca, L.-I.; Dan, V.; Ciomos, A.; Crisan, O.; Barsan, G. Studies and Investigation about the Attitude towards Sustainable Production, Consumption and Waste Generation in Line with Circular Economy in Romania. Sustainability 2018, 10, 865. [CrossRef]

47. Kianpour, K.; Jusoh, A.; Mardani, A.; Streimikiene, D.; Cavallaro, F.; Nor, K.M.; Zavadskas, E. Factors Influencing Consumers' Intention to Return the End of Life Electronic Products through Reverse Supply Chain Management for Reuse, Repair and Recycling. Sustainability 2017, 9, 1657. [CrossRef]

48. Meng, Q.; Zhu, H.; Li, Z.; Du, J.; Wang, X.; Jeong Kim, M. How Green Building Product Decisions from Customers Can Be Transitioned to Manufacturers: An Agent-Based Model. Sustainability 2018, 10, 3977. [CrossRef]

49. Delcea, C.; Cotfas, L.-A.; Trică, C.; Crăciun, L.; Molanescu, A. Modeling the Consumers Opinion Influence in Online Social Media in the Case of Eco-friendly Products. Sustainability 2019, 11, 1796. [CrossRef]

50. Wang, F.; Huisman, J.; Meskers, C.E.M.; Schluep, M.; Stevels, A.; Hagelüken, C. The Best-of-2-Worlds philosophy: Developing local dismantling and global infrastructure network for sustainable e-waste treatment in emerging economies. Waste Manag. 2012, 32, 2134-2146. [CrossRef]

51. Vaccari, M.; Vinti, G.; Cesaro, A.; Belgiorno, V.; Salhofer, S.; Dias, M.I.; Jandric, A. WEEE Treatment in Developing Countries: Environmental Pollution and Health Consequences-An Overview. Int. J. Environ. Res. Public Health 2019, 16, 1595. [CrossRef]

52. Arain, A.L.; Pummill, R.; Adu-Brimpong, J.; Becker, S.; Green, M.; Ilardi, M.; Van Dam, E.; Neitzel, R.L. Analysis of e-waste recycling behavior based on survey at a Midwestern US University. Waste Manag. 2020, 105, 119-127. [CrossRef] [PubMed]

53. Meneses, G.D.; Palacio, A.B. Recycling Behavior: A Multidimensional Approach. Environ. Behav. 2016, 37, 837-860. [CrossRef]

54. Rousta, K.; Bolton, K.; Lundin, M.; Dahlén, L. Quantitative assessment of distance to collection point and improved sorting information on source separation of household waste. Waste Manag. 2015, 40, $22-30$. [CrossRef] [PubMed] 
55. Ylä-Mella, J.; Keiski, R.L.; Pongrácz, E. Electronic waste recovery in Finland: Consumers' perceptions towards recycling and re-use of mobile phones. Waste Manag. 2015, 45, 374-384. [CrossRef] [PubMed]

56. Sivathanu, D.B. User's Perspective: Knowledge and Attitude towards E-Waste. Int. J. Appl. Environ. Sci. 2016, 11, 413-423.

57. Klöckner, C.A. A comprehensive model of the psychology of environmental behaviour-A meta-analysis. Glob. Environ. Chang. 2013, 23, 1028-1038. [CrossRef]

58. D'Adamo, I.; Gastaldi, M.; Rosa, P. Recycling of end-of-life vehicles: Assessing trends and performances in Europe. Technol. Forecast. Soc. Chang. 2020, 152, 119887. [CrossRef]

59. Wang, B.; Ren, C.; Dong, X.; Zhang, B.; Wang, Z. Determinants shaping willingness towards on-line recycling behaviour: An empirical study of household e-waste recycling in China. Resour. Conserv. Recycl. 2019, 143, 218-225. [CrossRef]

60. Doha, A.; Elnahla, N.; McShane, L. Social commerce as social networking. J. Retail. Consum. Serv. 2019, 47, 307-321. [CrossRef]

61. Asim, Y.; Malik, A.K.; Raza, B.; Shahid, A.R. A trust model for analysis of trust, influence and their relationship in social network communities. Telemat. Inf. 2019, 36, 94-116. [CrossRef]

62. Kujur, F.; Singh, S. Engaging customers through online participation in social networking sites. Asia Pac. Manag. Rev. 2017, 22, 16-24. [CrossRef]

63. Lim, H.; Kumar, A. Variations in consumers' use of brand online social networking: A uses and gratifications approach. J. Retail. Consum. Serv. 2017, 51, 450-457. [CrossRef]

64. Wang, F.; Jiang, W.; Li, X.; Wang, G. Maximizing positive influence spread in online social networks via fluid dynamics. Future Gener. Comput. Syst. 2018, 86, 1491-1502. [CrossRef]

65. Delcea, C.; Popa, C.D.S.; Boloş, M. Consumers' Decisions in Grey Online Social Networks. J. Grey Syst. 2015, $27,12-27$.

66. Chen, C.-C.; Chen, C.-W.; Tung, Y.-C. Exploring the Consumer Behavior of Intention to Purchase Green Products in Belt and Road Countries: An Empirical Analysis. Sustainability 2018, 10, 854. [CrossRef]

67. Piligrimienè, Z.; Žukauskaitè, A.; Korzilius, H.; Banytė, J.; Dovalienė, A. Internal and External Determinants of Consumer Engagement in Sustainable Consumption. Sustainability 2020, 12, 1349. [CrossRef]

68. Burns, K.N.; Sun, K.; Fobil, J.N.; Neitzel, R.L. Heart Rate, Stress, and Occupational Noise Exposure among Electronic Waste Recycling Workers. Int. J. Environ. Res. Public Health 2016, 13, 140. [CrossRef]

69. Barletta, I.; Larborn, J.; Mani, M.; Johannson, B. Towards an Assessment Methodology to Support Decision Making for Sustainable Electronic Waste Management Systems: Automatic Sorting Technology. Sustainability 2016, 8, 84. [CrossRef]

70. Efthymiou, L.; Mavragani, A.; Tsagarakis, K.P. Quantifying the Effect of Macroeconomic and Social Factors on Illegal E-Waste Trade. Int. J. Environ. Res. Public Health 2016, 13, 789. [CrossRef]

71. Kusch, S.; Hills, C.D. The Link between e-Waste and GDP-New Insights from Data from the Pan-European Region. Resources 2017, 6, 15. [CrossRef]

72. Ramayah, T.; Lee, J.W.C.; Lim, S. Sustaining the environment through recycling: An empirical study. J. Environ. Manag. 2012, 102, 141-147. [CrossRef] [PubMed]

73. Oakley, R.L.; Salam, A.F. Examining the impact of computer-mediated social networks on individual consumerism environmental behaviors. Comput. Hum. Behav. 2014, 35, 516-526. [CrossRef]

74. Park, N.; Yang, A. Online environmental community members' intention to participate in environmental activities: An application of the theory of planned behavior in the Chinese context. Comput. Hum. Behav. 2012, 28, 1298-1306. [CrossRef]

75. Keramitsoglou, K.M.; Tsagarakis, K.P. Public participation in designing a recycling scheme towards maximum public acceptance. Resour. Conserv. Recycl. 2013, 70, 55-67. [CrossRef]

76. Barr, S.; Gilg, A.W.; Ford, N.J. Differences between household waste reduction, reuse and recycling behaviour: A study of reported behaviours, intentions and explanatory variables. Environ. Waste Manag. 2001, 4, 69-82.

77. Sidique, S.F.; Lupi, F.; Joshi, S.V. The effects of behavior and attitudes on drop-off recycling activities. Resour. Conserv. Recycl. 2010, 54, 163-170. [CrossRef]

78. Knussen, C.; Yule, F.; MacKenzie, J.; Wells, M. An analysis of intentions to recycle household waste: The roles of past behaviour, perceived habit, and perceived lack of facilities. J. Environ. Psychol. 2004, 24, 237-246. [CrossRef] 
79. Zhang, D.; Huang, G.; Yin, X.; Gong, Q. Residents' Waste Separation Behaviors at the Source: Using SEM with the Theory of Planned Behavior in Guangzhou, China. Int. J. Environ. Res. Public Health 2015, 12, 9475-9491. [CrossRef]

80. Gonul Kochan, C.; Pourreza, S.; Tran, H.; Prybutok, V.R. Determinants and logistics of e-waste recycling. Int. J. Logist. Manag. 2016, 27, 52-70. [CrossRef]

81. Xu, L.; Ling, M.; Lu, Y.; Shen, M. Understanding Household Waste Separation Behaviour: Testing the Roles of Moral, Past Experience, and Perceived Policy Effectiveness within the Theory of Planned Behaviour. Sustainability 2017, 9, 625. [CrossRef]

82. Falcone, P.M.; Tani, A.; Tartiu, V.E.; Imbriani, C. Towards a sustainable forest-based bioeconomy in Italy: Findings from a SWOT analysis. For. Policy Econ. 2020, 110, 101910. [CrossRef]

83. IBM. IBM SPSS Amos. Available online: https://www.ibm.com/ro-en/marketplace/structural-equationmodeling-sem (accessed on 6 March 2020).

84. Spanos, Y.E.; Lioukas, S. An examination into the causal logic of rent generation: Contrasting Porter's competitive strategy framework and the resource-based perspective. Strateg. Manag. J. 2001, 22, 907-934. [CrossRef]

85. Delcea, C.; Bradea, I.-A. Patients' perceived risks in hospitals: A grey qualitative analysis. Kybernetes 2017, 46, 1408-1424. [CrossRef]

86. Fornell, C.; Larcker, D.F. Evaluating Structural Equation Models with Unobservable Variables and Measurement Error. J. Mark. Res. 1981, 18, 39-50. [CrossRef]

87. Brown, T.A. Confirmatory Factor Analysis for Applied Research, 2nd ed.; Methodology in the Social Sciences; The Guilford Press: New York, NY, USA; London, UK, 2015; ISBN 978-1-4625-1779-4.

88. Byrne, B.M. Structural Equation Modeling With AMOS: Basic Concepts, Applications, and Programming, 3rd ed.; Routledge: Abigdon, Great Britain, 2016; ISBN 978-1-317-63312-9.

89. Hu, L.; Bentler, P.M. Cutoff criteria for fit indexes in covariance structure analysis: Conventional criteria versus new alternatives. Struct. Equ. Model. Multidiscip. J. 1999, 6, 1-55. [CrossRef]

90. Harrington, D. Confirmatory Factor Analysis; Pocket Guides to Social Work Research Methods; Oxford University Press: Oxford, NY, USA, 2009; ISBN 978-0-19-533988-8.

91. Paswan, A.; D'Souza, D.; Zolfagharian, M.A. Toward a Contextually Anchored Service Innovation Typology. Decis. Sci. 2009, 40, 513-540. [CrossRef]

92. Bandura, A. Social Foundations of Thought and Action: A Social Cognitive Theory, 1st ed.; Prentice Hall: Englewood Cliffs, NJ, USA, 1985; ISBN 978-0-13-815614-5.

93. Wang, Z.; Guo, D.; Wang, X. Determinants of residents' e-waste recycling behaviour intentions: Evidence from China. J. Clean. Prod. 2016, 137, 850-860. [CrossRef]

94. Ma, J.; Hipel, K.W.; Hanson, M.L.; Cai, X.; Liu, Y. An analysis of influencing factors on municipal solid waste source-separated collection behavior in Guilin, China by Using the Theory of Planned Behavior. Sustain. Cities Soc. 2018, 37, 336-343. [CrossRef]

95. Chan, L.; Bishop, B. A moral basis for recycling: Extending the theory of planned behaviour. J. Environ. Psychol. 2013, 36, 96-102. [CrossRef]

96. Khan, F.; Ahmed, W.; Najmi, A. Understanding consumers' behavior intentions towards dealing with the plastic waste: Perspective of a developing country. Resour. Conserv. Recycl. 2019, 142, 49-58. [CrossRef]

97. Ewing, G. Altruistic, Egoistic, and Normative Effects on Curbside Recycling. Environ. Behav. 2001, 33, 733-764. [CrossRef]

98. Vining, J.; Ebreo, A. What Makes a Recycler? A Comparison of Recyclers and Nonrecyclers. Environ. Behav. 1990, 22, 55-73. [CrossRef]

99. Derksen, L.; Gartrell, J. The Social Context of Recycling. Am. Sociol. Rev. 1993, 58, 434-442. [CrossRef]

100. Margai, F.L. Analyzing Changes in Waste Reduction Behavior in a Low-Income Urban Community Following a Public Outreach Program. Environ. Behav. 1997, 29, 769-792. [CrossRef]

101. Scott, D. Equal Opportunity, Unequal Results: Determinants of Household Recycling Intensity. Environ. Behav. 1999, 31, 267-290. [CrossRef]

102. Saphores, J.-D.M.; Nixon, H.; Ogunseitan, O.A.; Shapiro, A.A. Household Willingness to Recycle Electronic Waste: An Application to California. Environ. Behav. 2006, 38, 183-208. [CrossRef]

103. Oskamp, S.; Harrington, M.J.; Edwards, T.C.; Sherwood, D.L.; Okuda, S.M.; Swanson, D.C. Factors Influencing Household Recycling Behavior. Environ. Behav. 1991, 23, 494-519. [CrossRef] 
104. Corral-Verdugo, V. Dual 'realities' of conservation behavior: Self-reports vs. Observations of re-use and recycling behavior. J. Environ. Psychol. 1997, 17, 135-145. [CrossRef]

105. Werner, C.M.; Turner, J.; Shipman, K.; Shawn Twitchell, F.; Dickson, B.R.; Bruschke, G.V.; von Bismarck, W.B. Commitment, behavior, and attitude change: An analysis of voluntary recycling. J. Environ. Psychol. 1995, 15, 197-208. [CrossRef]

106. Schultz, P.W.; Oskamp, S.; Mainieri, T. Who recycles and when? A review of personal and situational factors. J. Environ. Psychol. 1995, 15, 105-121. [CrossRef]

107. Johnson, C.Y.; Bowker, J.M.; Cordell, H.K. Ethnic Variation in Environmental Belief and Behavior: An Examination of the New Ecological Paradigm in a Social Psychological Context. Environ. Behav. 2004, 36, 157-186. [CrossRef]

108. Gamba, R.J.; Oskamp, S. Factors Influencing Community Residents' Participation in Commingled Curbside Recycling Programs. Environ. Behav. 1994, 26, 587-612. [CrossRef]

109. Do Valle, P.O.; Reis, E.; Menezes, J.; Rebelo, E. Behavioral Determinants of Household Recycling Participation: The Portuguese Case. Environ. Behav. 2004, 36, 505-540. [CrossRef]

110. Darby, L.; Obara, L. Household recycling behaviour and attitudes towards the disposal of small electrical and electronic equipment. Resour. Conserv. Recycl. 2005, 44, 17-35. [CrossRef]

111. Arcury, T.A.; Scollay, S.J.; Johnson, T.P. Sex differences in environmental concern and knowledge: The case of acid rain. Sex Roles 1987, 16, 463-472. [CrossRef]

112. Wang, Z.; Zhang, B.; Yin, J.; Zhang, X. Willingness and behavior towards e-waste recycling for residents in Beijing city, China. J. Clean. Prod. 2011, 19, 977-984. [CrossRef]

113. Domina, T.; Koch, K. Convenience and Frequency of Recycling: Implications for Including Textiles in Curbside Recycling Programs. Environ. Behav. 2002, 34, 216-238. [CrossRef]

114. Perry, G.D.R.; Williams, I.D. The participation of ethnic minorities in kerbside recycling: A case study. Resour. Conserv. Recycl. 2007, 49, 308-323. [CrossRef]

115. Granzin, K.L.; Olsen, J.E. Characterizing Participants in Activities Protecting the Environment: A Focus on Donating, Recycling, and Conservation Behaviors. J. Public Policy Mark. 1991, 10, 1-27. [CrossRef]

116. Hansmann, R.; Bernasconi, P.; Smieszek, T.; Loukopoulos, P.; Scholz, R.W. Justifications and self-organization as determinants of recycling behavior: The case of used batteries. Resour. Conserv. Recycl. 2006, 47, 133-159. [CrossRef]

(C) 2020 by the authors. Licensee MDPI, Basel, Switzerland. This article is an open access article distributed under the terms and conditions of the Creative Commons Attribution (CC BY) license (http://creativecommons.org/licenses/by/4.0/). 